\title{
Pennsylvanian cordaitaleans of the Dobrudzha Coal Basin (Bulgaria)
}

\author{
Zbyněk Šimůnek ${ }^{1}$, Yanaki Tenchov ${ }^{2}$ \\ ${ }^{1}$ Czech Geological Survey, Klarov 3/131, 11821 Praha 1, Czech Republic, email: zbynek.simunek@geology.cz \\ ${ }^{2}$ Geological Institute, Bulgarian Academy of Sciences, Acad. G. Bonchev St. Bl. 24, 1113 Sofia, Bulgaria, \\ email:ytenchov@abv.bg
}

(Accepted in revised form November 2011)

\begin{abstract}
The cordaitaleans are an important plant group in the Westphalian and Stephanian (Bashkirian, Moscovian and Kasimovian) of the Dobrudzha Basin. Small fragments of Cordaites leaves from bore cores are difficult to classify, therefore cuticular analysis has been used in their study. As a result five new species have been erected: Cordaites mogilishtianus, Cordaites makedonkanus, Cordaites dobrudzhanus, Cordaites vraninoensis and Cordaites gurkovoensis. Three species from the Bohemian Massif, namely Cordaites idae, C. schatzlarensis and C. cf. melnicensis also occur in the Dobrudzha Basin. Due to poor preservation, three samples from the Dobrudzha Basin cannot be determined to species and are here described as Cordaites sp. A, Cordaites sp. B and Cordaites sp. C. Most of the Dobrudzha Basin Cordaites belong to the Cordaites cuticular group B (Šimůnek, 2007) which is characterized by single or double stomatal rows on the abaxial cuticle.
\end{abstract}

Šimůnek, Z., Tenchov, Y. 2011. Pennsylvanian cordaitaleans of the Dobrudzha Coal Basin (Bulgaria). Geologica Balcanica 40(1-3), 39-73.

Key words: Cordaites, cuticular anylysis, Carboniferous (Bashkirian, Moscovian, Kasimovian), Dobrudzha Basin, Bulgaria.

\section{INTRODUCTION}

The Cordaitanthales are an extinct group of gymnosperms that can be traced from the Mississipian to Permian. During the Pennsylvanian they inhabited lowland peat mires where they either formed more or less monotypic stands or were part of mixed vegetation types growing interspersed among calamites, tree ferns and lycophytes (Raymond and Phillips, 1983; Triwett and Rothwell, 1985; Raymond, 1988; Di Michele and Phillips, 1994). Similar types of forests are also known from the intramountain basins (Šimůnek et al., 2009; Opluštil et al., 2009). Other forms lived in poorly to well-drained mineral soils, forming fire-prone communities on drier sites (Scott et al., 1997; Falcon-Lang, 2003a-c; FalconLang et al., 2004). A few gigant forms grew in upland settings (Falcon-Lang and Scott, 2000, Falcon-Lang and Bashforth, 2004, 2005). Some cordaitaleans are suggested as inhabiting marine-influenced costal mires and thus represent the earliest known mangrove communities. However, several key physiological adaptations to growth in brackish water are absent in the trees, therefore the term "mangrove" for these fossil forests is probably inappropriate (Plaziat et al., 2001).

Adpression fossils of leaves represent the most frequently encountered parts of the plants. Bedding planes revealing monotypic assemblages of Cordaites leaves are known from numerous sites in Europe and North America (e.g. Martín-Closas and Galtier, 2005). Cordaitalean leaves are typically strap-shaped, some reaching $\sim 1 \mathrm{~m}$ in length and up to $20 \mathrm{~cm}$ in width (Taylor et al., 2009).

The cordaitaleans are distributed through the whole sequence of the Dobrudzha Basin in Bulgaria (Fig. 1), being more frequent in its upper part (Gurkovo Formation). The Dobrudzha Basin plant fossils are only known from subsurface sections, therefore the dimensions of cordaitalean remains are limited to the dimensions of the cores. The problem with using cordaite leaves for stratigraphic correlation is their taxonomic identification. The classification of Cordaites species was traditionally based on leaf shape and venation (Cleal et al., 2009). However, there is a large variability in both leaf shape and venation which makes idenfication of leaf fragments from core samples very difficult.

Cordaite cuticle studies started in the 1960s (Harms and Leisman, 1961; Barthel, 1962 a, b, 1964; Pant and Verma, 1964; Ledran, 1966; Rabitz, 1966) although usually as an appendix to the morphological description of species. It was shown that individual morphological species [e.g. Cordaites principalis (Germar) Geinitz] could have several types of cuticles and consequently could not represent one biological species. There are two principal approaches of classifying cuticles (Barclay et al., 2007): 1) cuticles are assigned to morphotypes within a species, 
2) cuticles are described as new fossil genera and species. The use and description of cordaite morphotypes seems to be meaningless, as e.g. cuticular morphotypes of Cordaites principalis (Germar) Geinitz belong to several biological species. Cuticles of cordaites are diverse and better reflect the diversity of the group than the leaf shape and venation (Šimůnek, 2007). During the cordaite study from the Dobrudzha Basin we chose to use the same approach as in Šimůnek (2007), i.e. to give a new specific name to each different cuticular form.

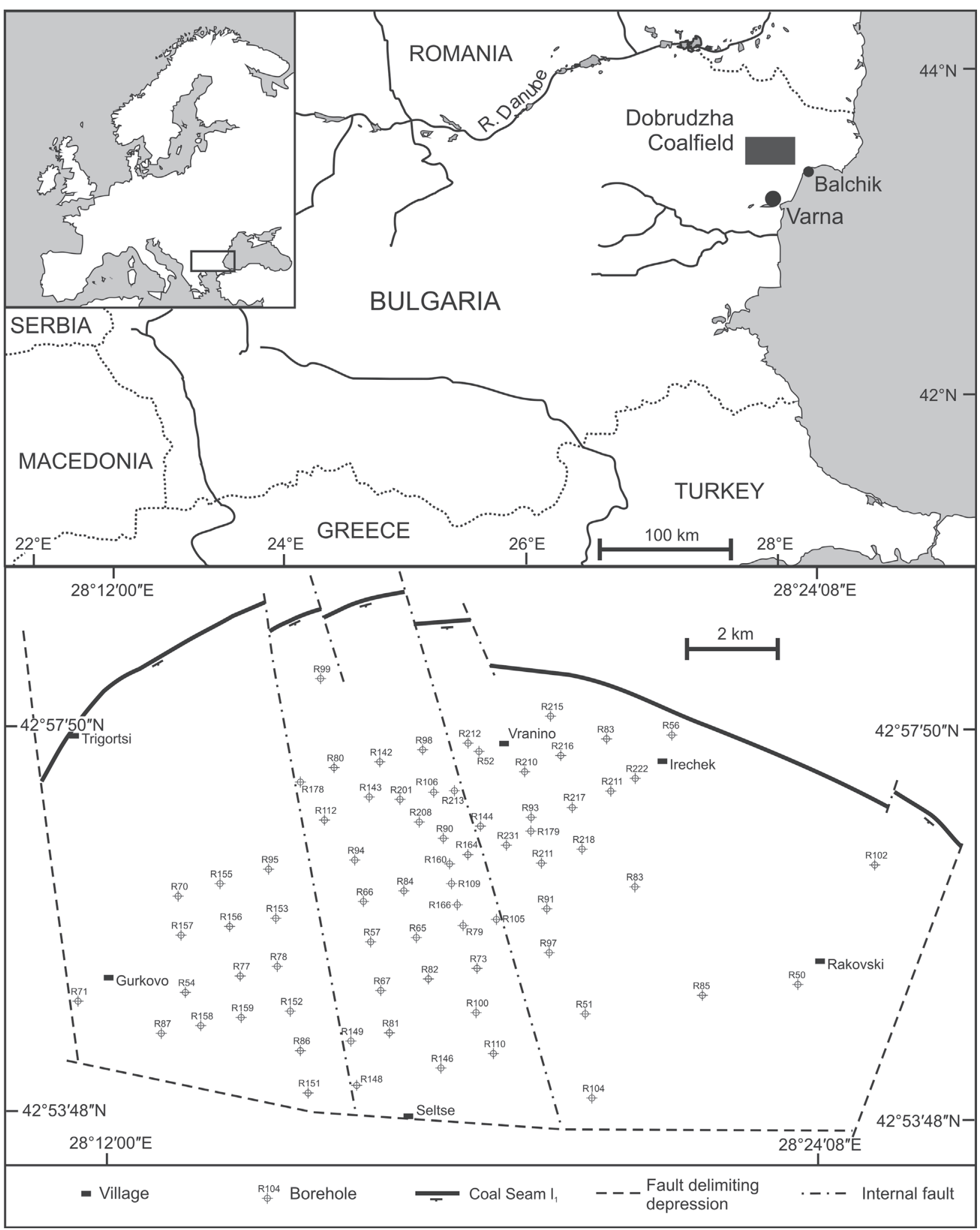

Fig. 1. Position and boundaries of the Dobrudzha Basin with borehole location (Courtesy by C. J. Cleal) 


\section{MATERIAL AND METHODS}

Thirty-six cores with Cordaites samples from 18 boreholes were studied. Forteen Cordaites leaves were macerated for cuticular study. These samples are of different ages - from the Langsettian to Cantabrian Stages in the Mogiliste, Vranino and Gurkovo formations. Details about samples are given in the descriptions of the individual species.

Cuticles were prepared according to the method described by Kerp (1990), Krings and Kerp (1997) and Kerp and Krings (1999). Coalified leafy fragments were separated from the rock by means of a needle or hydrofluoric acid. These fragments were bleached in Schulze's reagent $(40 \%$ $\mathrm{HNO}_{3}$ with crystals of $\mathrm{KClO}_{3}$ ) for 16 to 28 hours. Petri dishes with leaf fragments and Schulze's reagent were heated to $30^{\circ}$ to $40^{\circ} \mathrm{C}$ for 1 to 2 hours to accelerate the maceration process, if necessary. After the treatment in Schulze's reagent, cuticles were washed in water and subsequently in $2 \%$ or $10 \%$ potassium hydroxide $(\mathrm{KOH})$ and finally rinsed in distilled water. Some cuticles were restained with safranin, Bismark brown, malachite green and neutral red (Krings, 2000) for 1 to 2 hours to accentuate the anticlinal walls and stomata. Before embedding in glycerine-gelatine slides, the cuticles were dehydratated in pure glycerine. The remaining cuticular fragments were affixed to metal stubs for observation under a Cam Scan scanning electron microscope.

Recently, two cuticular characteristics have been used for the assessment of palaeoecological environment, mainly palaeo- $\mathrm{CO}_{2}$ concentrations: stomatal density and stomatal index. Stomatal density (SD) is the total number of stomata per unit area. Stomatal index (SI) is the number of stomata expressed as a percentage of the total number of cells per unit area: SI $=100 \times$ (total number of stomata / total number of stomata + total number of epidermal cells) (Poole and Kürschner, 1999). Stomatal index was first used by Salisbury (1927).

The use of stomatal density for paleoecological evaluations (palaeo- $\mathrm{CO}_{2}$ concentrations) is complicated by many unknown factors that influenced SD and SI values. Stomatal density within one big leaf (like in Cordaites) can vary in different parts. Sun leaves and shade leaves have usually a different stomatal density. These factors cannot be estimated in the fossil material (Poole and Kürschner, 1999). Moreover, cordaitaleans are an extinct group without relatives within extant pants. Thus, the SD and SI values from fossil plants could be compared with those in living plants. The SD and SI are useful rather in species descriptions than on the paleoecological interpretations.

\section{GEOLOGICAL SETTING}

The Dobrudzha Basin is $500 \mathrm{~km}^{2}$ in size and is situated in northwest Bulgaria near the Black Sea (Fig. 2). Marine

Fig. 2. Lithostratigraphic subdivision of Carboniferous succession in the Dobrudzha Coal Basin: Pendl. - Pendleian, Ar Arnsbergian, Ye - Yeadonian; Vr - Vranino, Vel - Velkovo, PoPolyatsi; 1 - Coals, 2 - Claystones, 3 - Siltstones, 4 - Sandstones, 5 - a - Pebbles, b - Claystones, c - Coals, 6 - Tonsteins, 7 Volcanites, Volcanoslastics, 8 - Erosive boundary

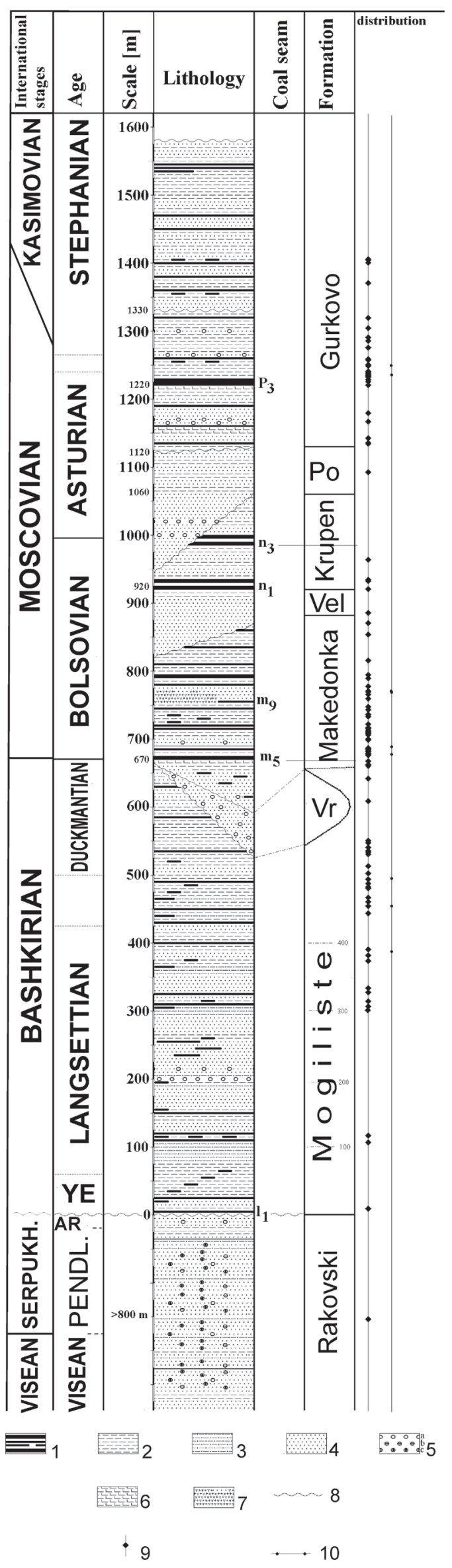


Visean to Serpukhovian age deposits lie unconformably on Devonian limestones and are covered by continental coal-bearing deposits of Serpukhovian (Namurian "A") age. Alluvial, swamp and lacustrine deposits, 1,600 m thick, of Bashkirian (Namurian "C") to late Moscovian (early Cantabrian) age were assigned to the Balchik Group and divided into seven formations (Fig. 2).

The Mogilishte Formation corresponds to the Yeadonian to lower Duckmantian substages (Tenchov, 2005). It contains up to 70 coal seams with an average thickness of $0.2-0.6 \mathrm{~m}$. Coal deposition is concentrated to its middle and upper part.

The overlying Vranino Formation is composed of medium-grained sandstones and conglomerates (Tenchov, 2005). The coals are rare and scattered.

The Makedonka Formation is divided into two members at the level of a basin-wide tonstein. The lower member is composed of volcanomictic sandstones (Tenchov, 1993) and contains up to 12 coal seams with a maximum thickness of $3 \mathrm{~m}$. The upper member is mainly composed of claystones and siltstones. The proportion of sandstones increases upwards through the upper member. Seven coal seams occur continuously across the coalfield (Tenchov, 1993).

The Upper Bolsovian Velkovo Formation (Dimitrova and Cleal, 2007) is mainly composed of medium- to coarsegrained sandstones with clayish and anhydritic cements, and conglomeratic interbeds. The thickness of the formation varies from 40 to $133 \mathrm{~m}$. There is a rapid transition between the Velkovo and the overlaying Krupen formations.

The Krupen Formation (Bolsovian/Asturian) consists mainly of sandstones with four interbeds of siltstones, claystones and coals (Tenchov, 1993). The lower two coal seams are of boghead type (Tenchov, 1993). Four coal seams are developed in the Krupen Formation.

The Asturian Polyantsi Formation is bounded by two erosional surfaces, the upper one representing a short stratigraphic gap (Dimitrova and Cleal, 2007). The formation consists of sandstones and conglomerates (Tenchov, 1993).

The Gurkovo Formation (Upper Asturian and Cantabrian), which is divided into three members, is mainly composed of sandstones and conglomerates. In the upper part, synchronous volcanic activity has been established together with lake deposits.

\section{SYSTEMATIC PART}

Order Cordaitanthales Meyen, 1984

Family Cordaitanthaceae

\section{Genus Cordaites Unger, 1850}

Type species. Cordaites barassifolius (Sternberg) Unger

General characteristics. The leaves are large, ribbonshaped or lanceolate, parallel-veined, hypo- or amphistomatic. The cuticles have several common features which do not necessarily occur in each species. Oblong cells and stomata are oriented parallel to veins. Cells of the abaxial (and sometimes also adaxial) epidermises are differentiated into stomatiferous (intercostal) and non-stomatiferous (costal) bands. The stomatiferous band is sometimes formed by stomatal rows. The stomata are haplocheilic.
The stomatal complex is formed by two usually sunken elliptical guard cells, two lateral subsidiary cells and two polar subsidiary cells.

Five groups of Cordaites cuticular morphotypes were defined by Simůnek (2007):

A - Stomata arranged in rare, poorly defined stomatal rows;

B - Stomata arranged in well-defined single or double stomatal rows;

C - Stomata in well-defined double or multiple stomatal rows that are connected into stomatiferous bands;

D - Cells of stomatiferous bands differing from those of the non-stomatiferous bands; the stomata within stomatiferous bands are irregularly dispersed;

E - Stomata arranged into stomatiferous bands separated by non-stomatiferous bands. The subsidiary and ordinary cells of stomatiferous and non-stomatiferous bands are of the same shape.

\section{Cordaites of the Langsettian (Westphalian A) Substage}

\section{Cordaites mogilishtianus Šimůnek and Tenchov $\backslash$ sp. nov. (Figs 3, 4)}

Holotype: Here designated (Fig. 4a), Czech Geological Survey, Prague, inv. No. ZŠ 452, coll. Y. Tenchov (orig. No. 9869).

Derivation of name: After Mogilishte village.

Type locality: Vranino locality, borehole R 80 , depth $1970 \mathrm{~m}$.

Type horizon: Mogilishte Formation, Pennsylvanian, Langsettian Substage (Bashkirian Stage).

Material: Slides 535/1-5.

Diagnosis: Relatively narrow hypostomatic leaves with parallel margins. Venation is sparse; $3-5$ thin veins alternate with one thick vein. Cells of adaxial and abaxial cuticles are mostly oblong. Stomata in stomatal rows

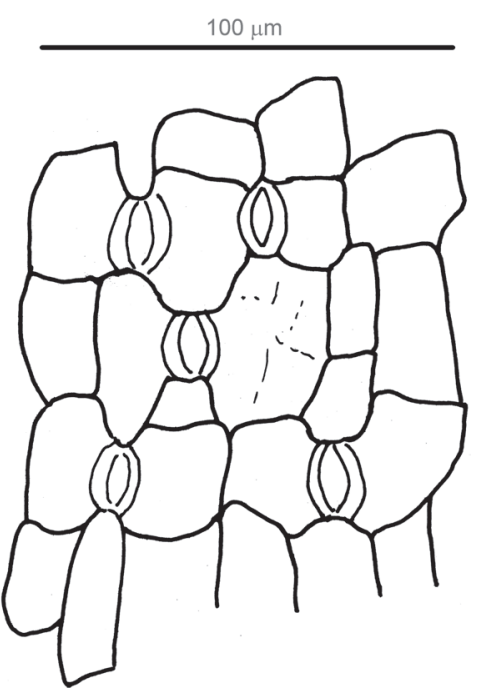

Fig. 3. Cordaites mogilishtianus Šimůnek and Tenchov sp. nov. Abaxial cuticle with position of stomata. Slide 535/5 (Fig. 4h). Scale bar $100 \mu \mathrm{m}$. 

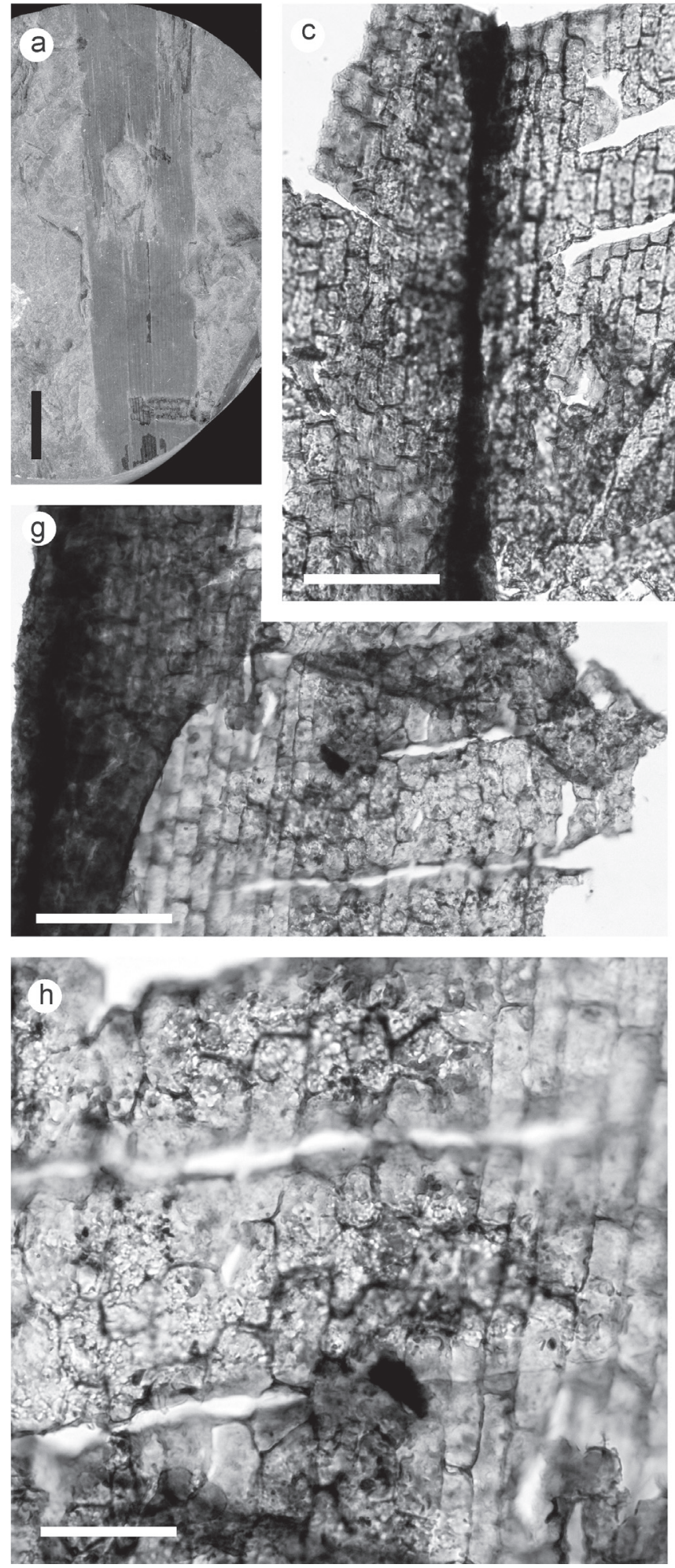
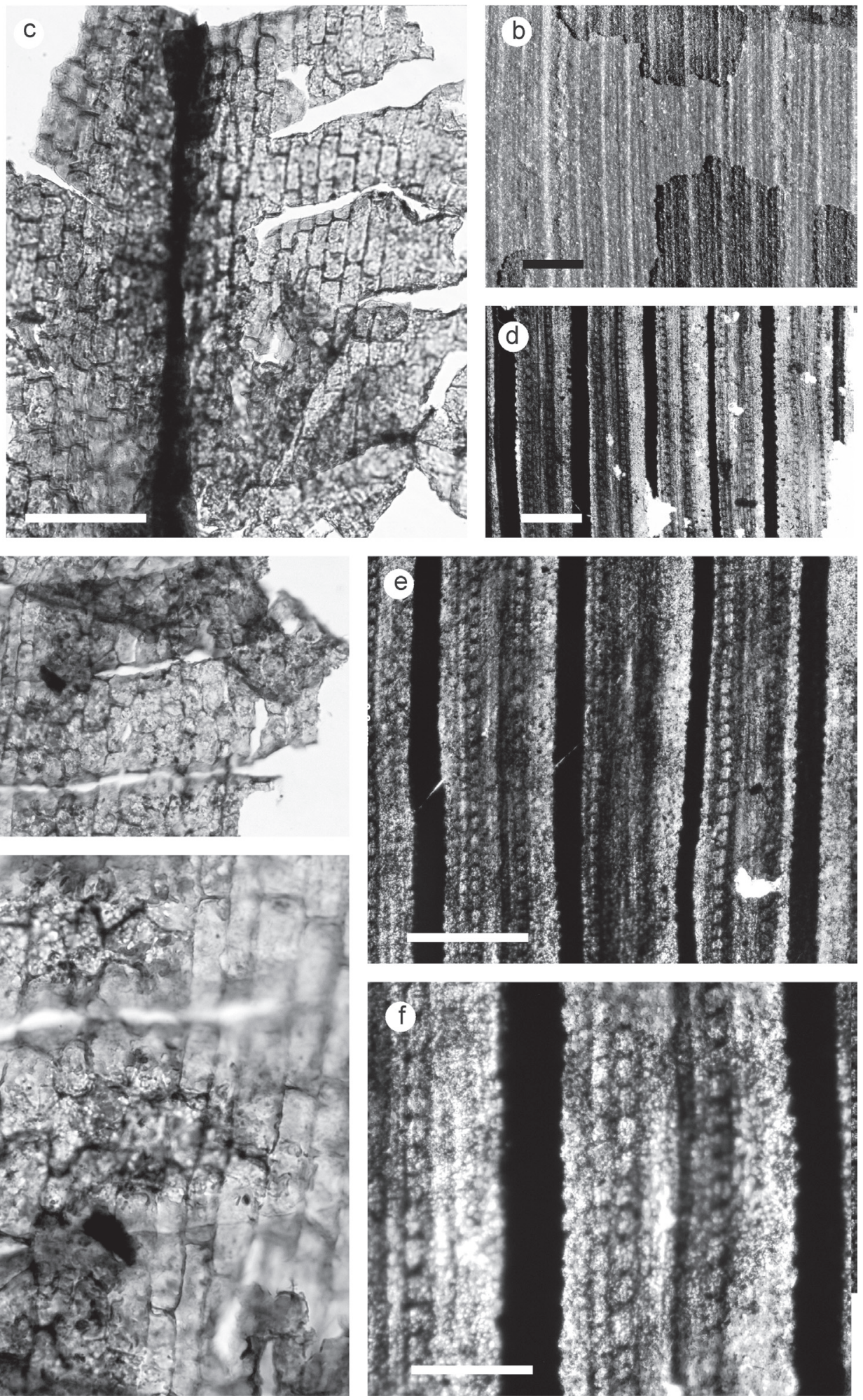

Fig. 4. Cordaites mogilishtianus Šimůnek and Tenchov sp. nov., Vranino locality, borehole R 80, depth 1970 m, Mogilishte Formation, Langsettian

a - Leaf fragment No. ZŠ 452 (orig. No. 9896), scale bar $1 \mathrm{~cm}$;

b - Venation detail from Fig. 4a, scale bar $1 \mathrm{~mm}$;

c - Adaxial cuticle (left) and abaxial cuticle (right), slide 535/5, scale bar $100 \mu \mathrm{m}$;

d - Naturally macerated leaves with coalified sclerenchymatous tissue and vascular bands, slide 535/2, scale bar $200 \mu \mathrm{m}$;

e - Detail from Fig. 4d, scale bar $200 \mu \mathrm{m}$;

$\mathrm{f}-$ Detail from Fig. 4e, scale bar $100 \mu \mathrm{m}$;

$\mathrm{g}$ - Abaxial cuticle with stomatiferous band (left), slide 535/5, scale bar $100 \mu \mathrm{m}$;

$\mathrm{h}$ - Detail of abaxial cuticle from Fig. 4g, stomatiferous band on the left, scale bar $50 \mu \mathrm{m}$. 
(numerous irregularities) forming stomatiferous bands. Lateral subsidiary cells oblong.

Description of holotype. Leaf fragment, $70 \mathrm{~mm}$ long and $17 \mathrm{~mm}$ wide. The venation density is $18-20$ veins per $\mathrm{mm}$. Three to five thin veins alternate with one thick vein (Fig. 4b). Most cuticles are naturally macerated (Fig. 4d-f) where black 'thick' veins and dark structures of 'thin' veins are visible.

Adaxial cuticle. Only small fragments have been preserved. The cuticles near the leaf margin are without stomata (Fig. 4c). Adaxial cuticle is formed by oblong cells, 20-60 $\mu \mathrm{m}$ long and 15-25 $\mu \mathrm{m}$ wide. The costal and intercostal fields are not distinguishable.

Abaxial cuticle (Fig. $4 \mathrm{~g}-\mathrm{h}$ ) is formed by stomatiferous and non-stomatiferous bands. The stomatiferous bands, up to $250 \mu \mathrm{m}$ wide, are formed by 3-5 stomatal rows. There are often irregularities in stomatal rows (Fig. 3). The stomatiferous bands alternate with non-stomatiferous bands, up to $125 \mu \mathrm{m}$ wide. The cells of non-stomatiferous bands are oblong, 25-70 $\mu \mathrm{m}$ long and 10-20 $\mu \mathrm{m}$ wide. Stomatiferous bands contain cells of the same shape and stomatal complexes, 60-70 $\mu \mathrm{m}$ long and 40-50 $\mu \mathrm{m}$ wide. The sunken guard cells are elliptical, 25-30 $\mu \mathrm{m}$ long and $10-15 \mu \mathrm{m}$ wide. The polar subsidiary cells are oblong, elongated, 15-25 $\mu \mathrm{m}$ long and 12-15 $\mu \mathrm{m}$ wide. The lateral subsidiary cells are reniform or oblong, 35-50 $\mu \mathrm{m}$ long and 16-22 $\mu \mathrm{m}$ wide. The crypt is not developed. Stomatal density is about 160 stomata per $\mathrm{mm}^{2}$. The stomatal index is 10 .

Comparison. Very few Cordaites with preserved cuticles are known from the Langsettian Substage. All Cordaites species known from the Langsettian of the Upper Silesian Basin, Czech Republic, (C. karvinensis Šimůnek, C. silesiacus Šimůnek and C. sustae Šimůnek) (Šimůnek, 2007) have stomata irregularly or regularly dispersed on the abaxial cuticle. They do not form stomatal rows and bands. On the contrary, the Bulgarian species Cordaites mogilishtianus has stomatiferous bands. Stomatal complexes are arranged into stomatal rows, but there are many irregularities (Fig. 3). Lateral subsidiary cells are oblong and differ slightly from ordinary cells. Cordaites mogilishtianus is the oldest Cordaites forming stomatiferous bands. There are no other species to be confused with Cordaites mogilishtianus.

Remarks. The Type $\mathrm{C}$ is defined by stomatal rows joined into stomatiferous bands. Cordaites mogilishtianus can be classified as Type $\mathrm{C}$ with some reservation. The lateral subsidiary cells are similar to the ordinary cells, and there are some irregularities in the stomatal rows (Fig. 3). This species is the oldest known species of the Type C.

\section{Cordaites of the Duckmantian (Westphalian B) Substage}

\section{Cordaites idae Šimůnek (Figs 5, 6)}

2007 Cordaites idae Šimůnek, 120-121, fig. 20, pl. 12, fig. 11-14, pl.13, fig. 2-11, pl. 14, pl.15, fig. 1, 2.

Holotype: Šimůnek (2007), Fig. 20a, coll. Czech Geological Survey, No. ZŠ 219.

Type locality: Rtyně v Podkrkonoší, Nejedlý Mine, (formerly Ida Gallery), Intrasudetic Basin.

Type horizon: Žacléř Formation, Prkenný Důl-Žd'árky Member, Strážkovice Coals, Duckmantian (Bashkirian). Material: One specimen (No. ZŠ 453, (orig. No. 9392), slides 406/1-5) from the Makedonka locality, borehole R 95, depth 1822 m, Mogilishte Formation, Duckmantian Substage (Bashkirian Stage).

Description of hand specimen (Fig. 5a). The leaf dimensions are not possible to establish, as the leaf covers the whole core surface, $66 \mathrm{~mm}$ in diameter. The venation is moderately dense $-26-30$ veins per mm. One thick and one thin vein usually alternate. The thin veins are not always visible or present (Fig. 5b, c). The thick (principal) vein looks "doubled" with a small depression in the middle (Fig. 5b).

Adaxial cuticle (Figs 5d, e, 6a). The cells of the costal and intercostal areas are barely distinguisable. The shape of cells is oblong, their length varies between 45-90 $\mu \mathrm{m}$, and width between $15-30 \mu \mathrm{m}$. The anticlinal walls are straight or only slightly bent. Stomata are rarely present and are ungrouped on the adaxial surface. The guard cells are elliptical, 25-33 $\mu \mathrm{m}$ long and 20-23 $\mu \mathrm{m}$ wide. Polar subsidiary cells are similar to the ordinary cells, but they are shorter, square to rounded, 20-30 $\mu \mathrm{m}$ in diameter. Lateral subsidiary cells are oblong to reniform, 40-50 $\mu \mathrm{m}$ long and 15-23 $\mu \mathrm{m}$ wide, so the whole stomatal complex is $100-110 \mu \mathrm{m}$ long and $60-70 \mu \mathrm{m}$ wide. The stomatal density varies from 0 to 6 stomata per $1 \mathrm{~mm}^{2}$ and stomatal index from 0 to 0.7 .

Abaxial cuticle (Figs $5 f-i, 6 b-c)$. The cells are differentiated into simple or double stomatal (intercostal) rows and non-stomatiferous (costal) bands, 25-30 $\mu \mathrm{m}$ wide. All cells of the intercostal field (stomatal rows) belong to stomatal complexes. The non-stomatiferous bands are

Fig. 5. Cordaites idae Šimůnek, Makedonka locality, borehole R 95, depth 1822 m, Mogilishte Formation, Duckmantian. a - Leaf fragment No. ZŠ 453 (orig. No. 9392), scale bar $1 \mathrm{~cm}$;

$\mathrm{b}, \mathrm{c}-$ Venation details from different parts of the leaf from Fig. 5a, scale bar $1 \mathrm{~mm}$; d - Adaxial cuticle, slide 406/1, scale bar $100 \mu \mathrm{m}$;

e - A detail of stoma from adaxial cuticle, slide 406/4, scale bar $50 \mu \mathrm{m}$;

f - Abaxial cuticle with stomatal rows, slide 406/1, scale bar $100 \mu \mathrm{m}$;

$\mathrm{g}$ - Close up of abaxial cuticle with two stomatal rows, slide $406 / 1$, scale bar $50 \mu \mathrm{m}$;

$\mathrm{h}$ - Detail of a stoma, slide 406/1, scale bar $20 \mu \mathrm{m}$;

I - Detail of two stomata, slide 406/3, scale bar $20 \mu \mathrm{m}$; 

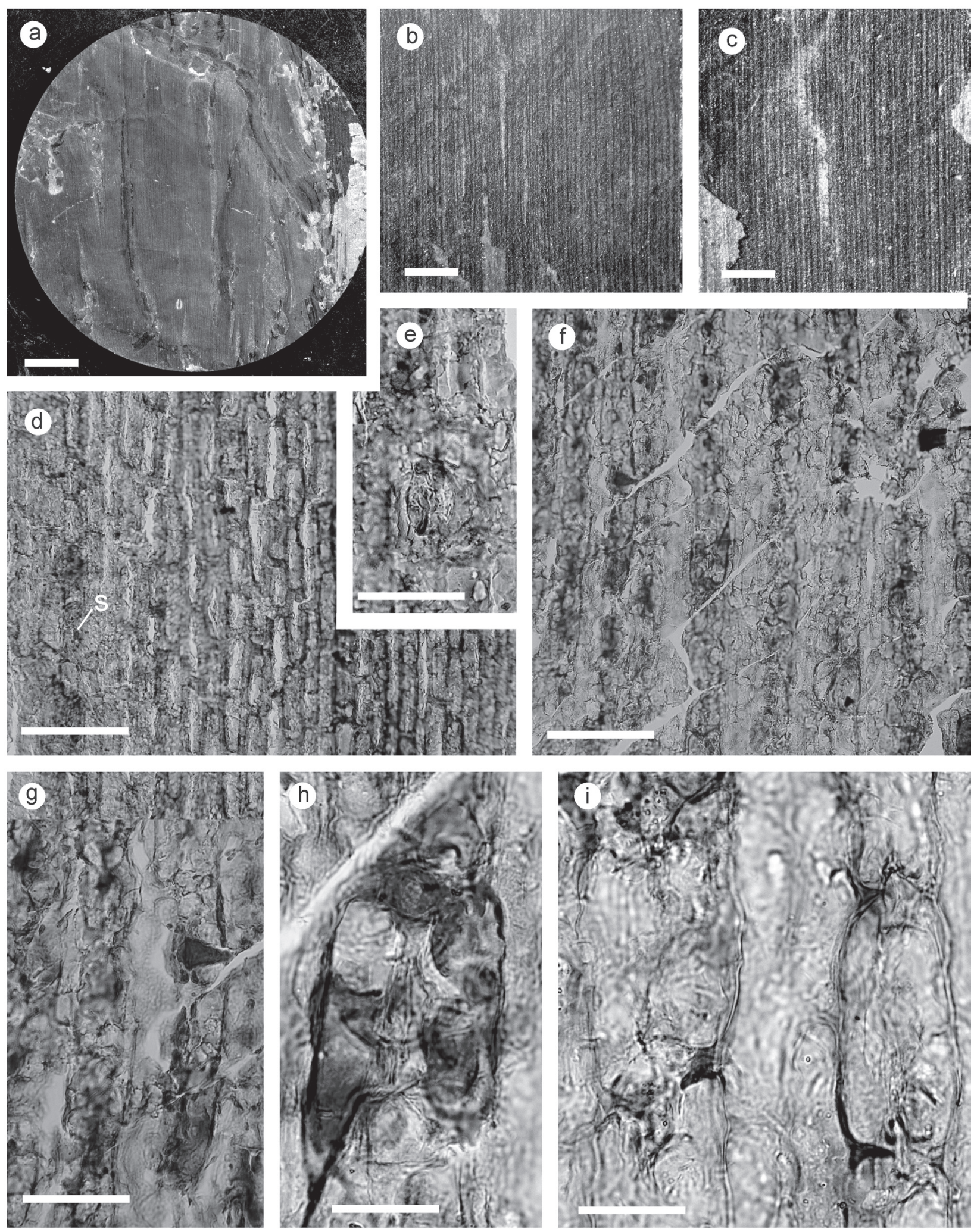

formed by 3-4 rows of costal cells which are elongated, oblong to trapezoidal, 35-65 $\mu \mathrm{m}$ long and 10-15 $\mu \mathrm{m}$ wide. The anticlinal walls are straight, or slightly bent. Stomatal complexes are formed by two guard cells, two polar and two lateral subsidiary cells. The pairs of guard cells are elliptical, sunken beneath the epidermis level, 20-25 $\mu \mathrm{m}$ long and $10 \mu \mathrm{m}$ wide. The stomatal complex (including subsidiary cells) is 50-60 $\mu \mathrm{m}$ long and 23-35 $\mu \mathrm{m}$ wide. The polar subsidiary cells are small, nearly isodiametric, rhomboidal, oval to rounded. They are about 

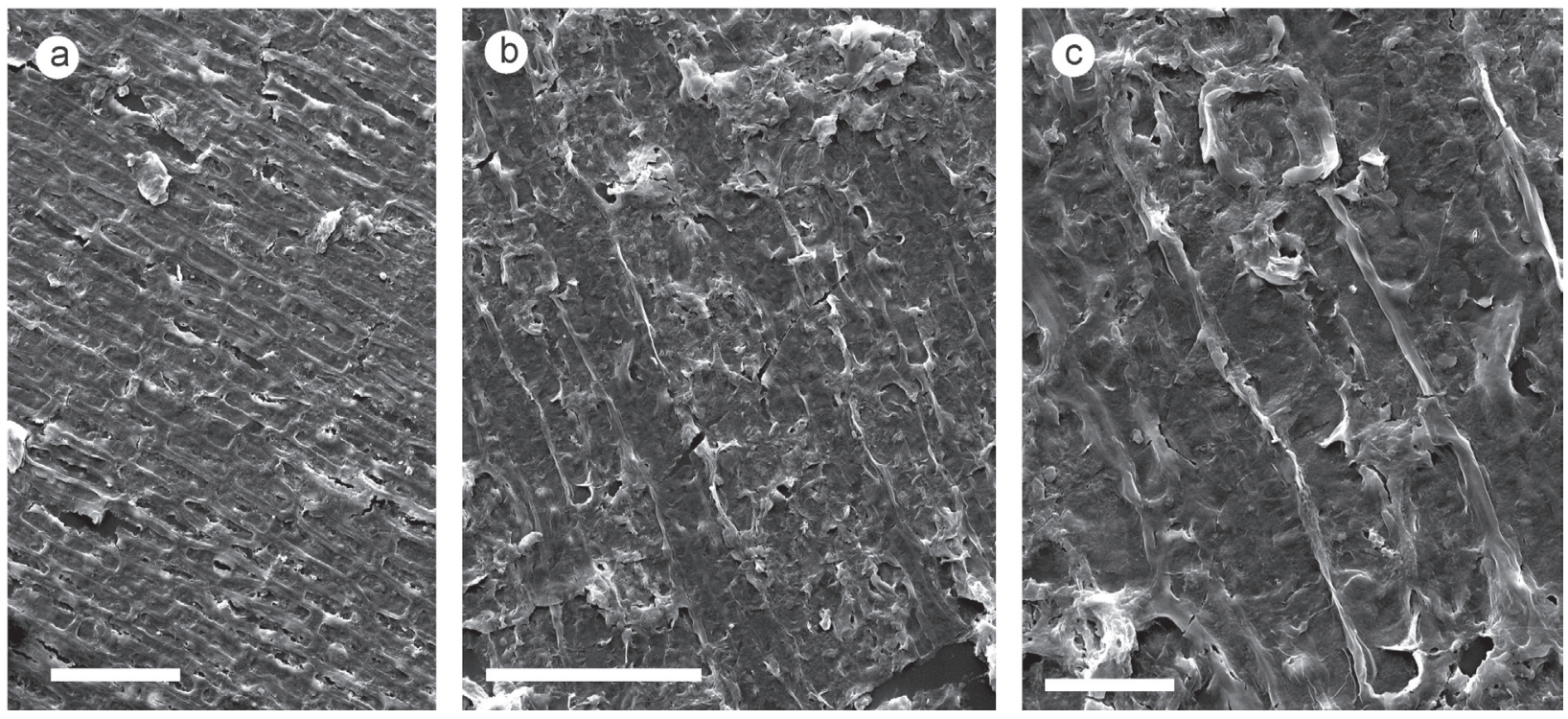

Fig. 6. Cordaites idae Šimůnek, Makedonka locality, borehole R 95, depth 1822 m, Mogilishte Formation, Duckmantian, SEM images, stub 26.

a - Abaxial cuticle, scale bar $100 \mu \mathrm{m}$;

b - Abaxial cuticle with stomatal rows, scale bar $100 \mu \mathrm{m}$;

$\mathrm{c}-$ Close up of a stomatal row in abaxial cuticle, scale bar $25 \mu \mathrm{m}$.

$10 \mu \mathrm{m}$ in diameter, or $10-15 \mu \mathrm{m}$ long and 3-9 $\mu \mathrm{m}$ wide. The lateral subsidiary cells are more or less oblong with rounded corners, $40-52 \mu \mathrm{m}$ long and $10-16 \mu \mathrm{m}$ wide. Polar subsidiary cells are common to two neighbouring stomata in a row, their lateral subsidiary cells are touching. The outer stomatal cavity (crypt) has a more or less square shape and constricts the space above the guard cells by arching of walls of lateral subsidiary cells towards the stomatal aperture. The stomatal density is about 280 stomata per $1 \mathrm{~mm}^{2}$ of the leaf blade. The value of stomatal index is 16 (including the non-stomatiferous band).

Comparison. Cordaites idae Šimůnek, 2007 has been described from the Intrasudetic Basin (Czech Republic). The venation densities of the Bohemian samples seem to be slightly higher (30-40 veins per $\mathrm{cm})$ than the Bulgarian samples (26-30 veins per $\mathrm{cm}$ ). There are 1-2 thin veins between each pair of thick veins. The characteristic features of this species are the prominent oblong subsidiary cells, the small, usually rhomboidal polar subsidiary cells, and the small, prominent, square crypt above guard cells. This stomatal type is also very distinctive and unlikely to be confused with other species forming stomatal rows. If cuticles of $C$. idae are not well preserved, especially the crypt, it could be confused with Cordaites schatzlarensis Šimůnek and Libertín, 2006. However, the latter species differs from $C$. idae by having more reniform lateral subsidiary cells, rounded polar subsidiary cells and the absence of a crypt. Both species have very similar adaxial cuticles. In the original description, $C$. idae was considered as hypostomatic and C. schatzlarenis as amphistomatic. Based on the Bulgarian material studied herein, it seems that both species are amphistomatic. Cordaites idae has a very low stomatal density on the adaxial cuti- cle (0-6 stomata per $\left.\mathrm{mm}^{2}\right)$. Stomata of the same structure occurs on the adaxial cuticle of a Bulgarian example of C. schatzlarenis with a stomatal density of $0-1$ stoma per $\mathrm{mm}^{2}$, whereas in the Czech Republic the stomatal density is $0-40$ per $\mathrm{mm}^{2}$. The adaxial cuticles of these species are evidently very similar and could not be distinguished from dispersed cuticles, whereas differences based on abaxial cuticles are evident.

\section{Cordaites schatzlarensis Šimůnek and Libertín (Figs 7-9)}

2006 Cordaites schatzlarensis Šimůnek et Libertín, p. 47-55, fig. 4, pls $1-3$, pl. 4 , figs. $1-2$.

2007 Cordaites schatzlarensis Šimůnek et Libertín - Šimůnek, p. 119120, fig. 19, pl. 12, fig. 13, fig 1.

Holotype: Czech Geological Survey, No.: ZŠ 102.

Type locality: Žacléř, Šverma mine (formerly Marie Julie), Intrasudetic Basin.

Type horizon: Žacléŕ Formation, Lampertice Member, Šverma mine coals - upper part, Carboniferous, Westphalian Stage, Duckmantian Substage (upper part) (Bashkirian Stage).

Material: Two specimens on one slab from the Makedonka locality, borehole R 95, depth $1822 \mathrm{~m}$, Mogilishte Formation, Duckmantian Substage, specimen No. ZЉ 454, (orig. No. 9392), slide nos: 412/1-8 and 413/1-3.

Description of hand specimens (Fig. 7a). The larger leaf fragment is preserved with an incomplete length of $67 \mathrm{~mm}$ and width of $15 \mathrm{~mm}$. The venation is relatively dense $-34-40$ veins per $\mathrm{mm}$. All veins are relatively thin having approximately same thickness. Small transverse wrinkles are observable between the veins (Fig. 7b). 

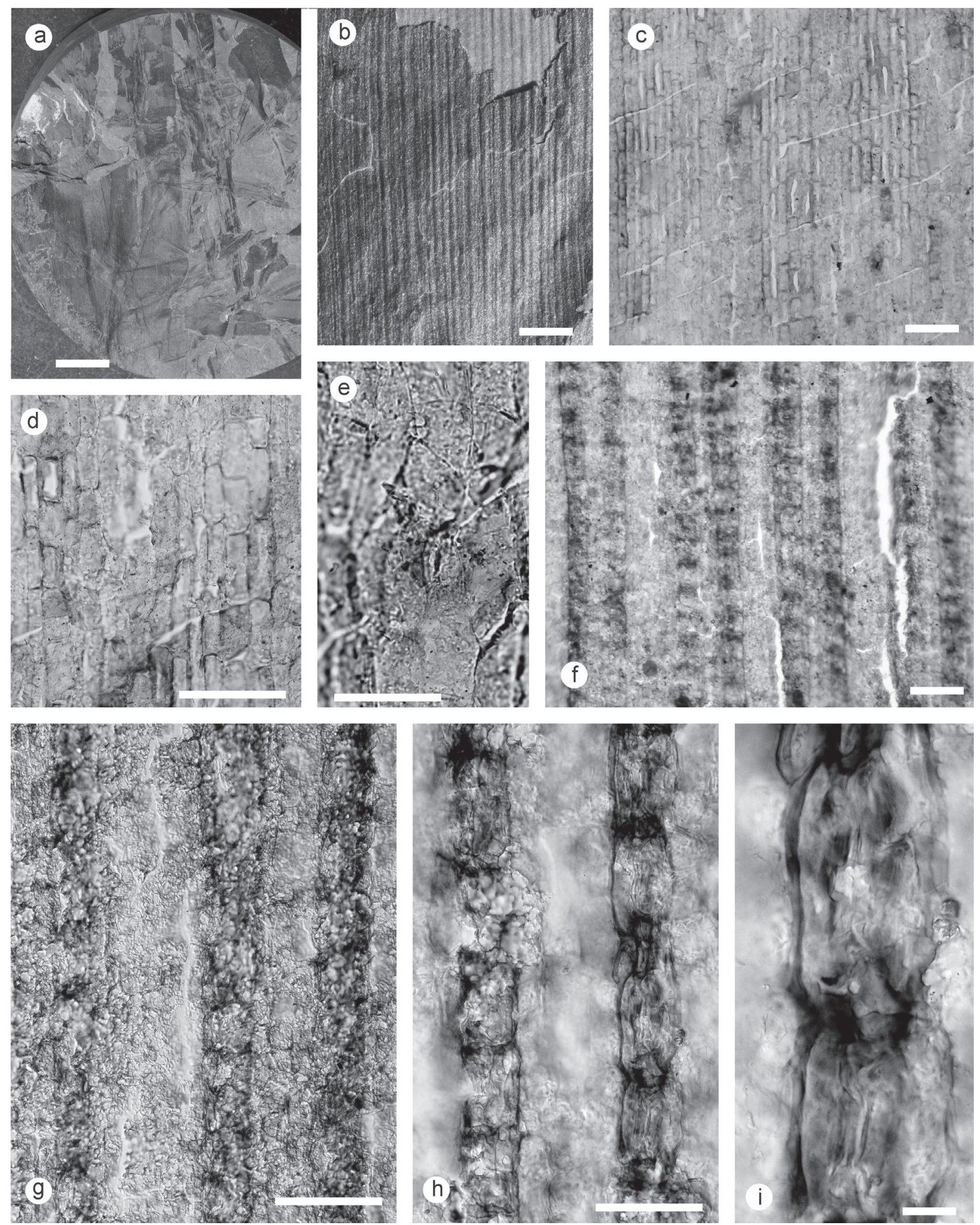

Fig. 7. Cordaites schatzlarensis Šimůnek et Libertín, Makedonka locality, borehole R 95, depth 1822 m, Mogilishte Formation, Duckmantian.

a - Leaf fragment No. ZŠ 454 (orig. no. 14433), scale bar $1 \mathrm{~cm}$;

$\mathrm{b}$ - Venation detail from Fig. A, scale bar $1 \mathrm{~mm}$;

c - Adaxial cuticle, slide 412/4, scale bar $100 \mu \mathrm{m}$;

d - Close up of adaxial cuticle from Fig. 7c, scale bar $100 \mu \mathrm{m}$;

e - A stoma on adaxial cuticle, slide $413 / 2$, scale bar $50 \mu \mathrm{m}$;

f - Abaxial cuticle with stomatal rows, slide 412/7, scale bar $100 \mu \mathrm{m}$;

g - Abaxial cuticle with three stomatal rows, slide 413/1, scale bar $100 \mu \mathrm{m}$;

$\mathrm{h}-$ Close up of two stomatal rows from Fig. $7 \mathrm{~g}$, scale bar $50 \mu \mathrm{m}$;

$\mathrm{i}$ - Detail of two stomata from Fig. $7 \mathrm{~h}$, scale bar $10 \mu \mathrm{m}$. 

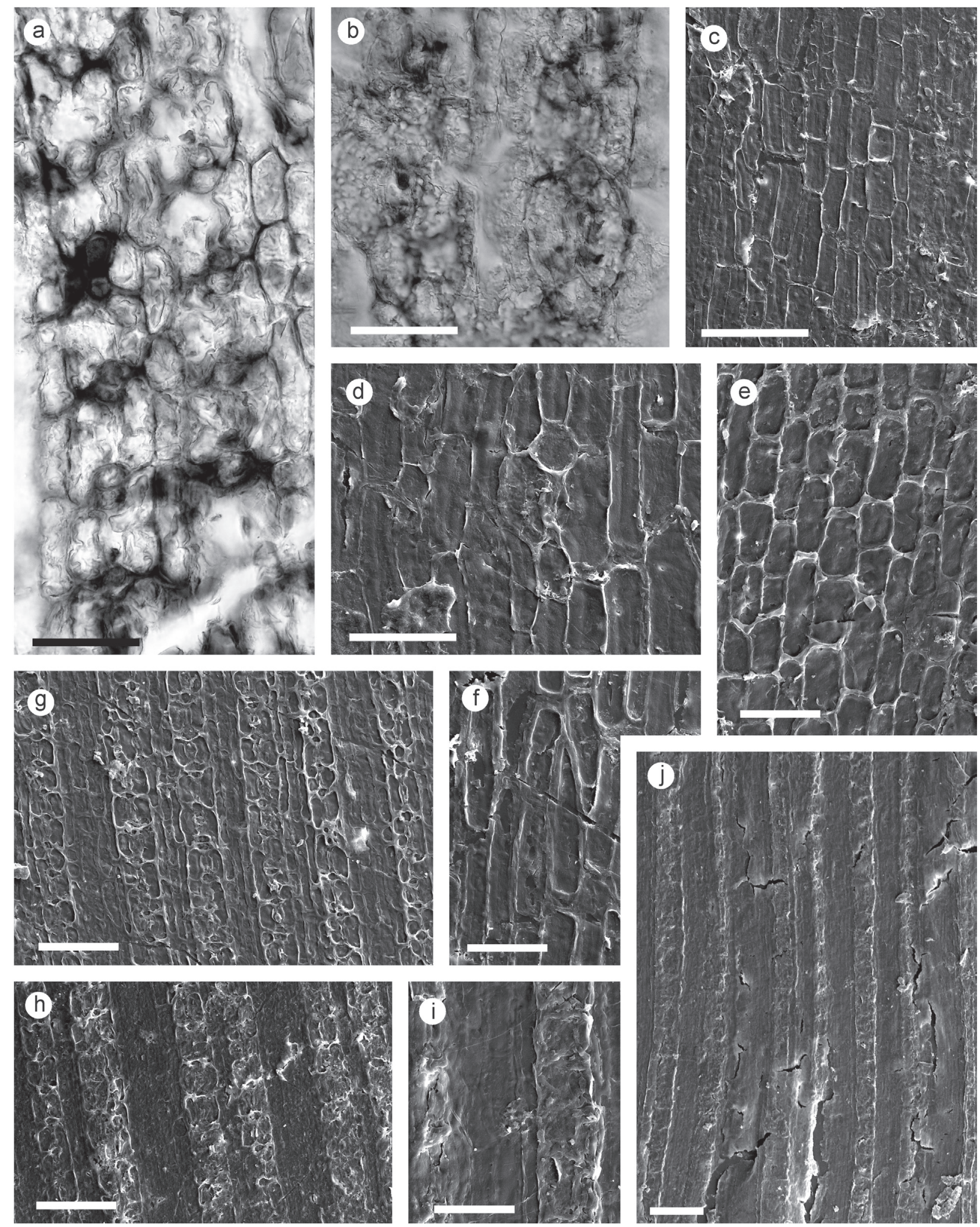

Fig. 8. Cordaites schatzlarensis Šimůnek and Libertín, Makedonka locality, borehole R 95, depth 1822 m, Mogilishte Formation, Duckmantian. (3-10 - SEM images, stub 29)

a - Abaxial cuticle with double stomatal row, slide 412/1, scale bar $50 \mu \mathrm{m}$;

b - Close up of two stomatal rows on abaxial cuticle, slide $413 / 3$, scale bar $50 \mu \mathrm{m}$;

$\mathrm{c}-\mathrm{f}$ - Inner view on adaxial cuticles, c - scale bar $100 \mu \mathrm{m}, \mathrm{d}$ - cuticle with isolated stomatal complex (s), scale bar $50 \mu \mathrm{m}, \mathrm{e}-\mathrm{scale}$ bar $50 \mu \mathrm{m}, \mathrm{f}$ - scale bar $50 \mu \mathrm{m}$;

$\mathrm{g}, \mathrm{h}$ - Inner view on abaxial cuticles. Note the different width between the stomatal rows, scale bar $100 \mu \mathrm{m}$;

$\mathrm{i}, \mathrm{j}$ - Outer view on the abaxial cuticle, note prominent stomatal rows, $\mathrm{i}$ - scale bar $50 \mu \mathrm{m}, \mathrm{j}$ - scale bar $100 \mu \mathrm{m}$. 

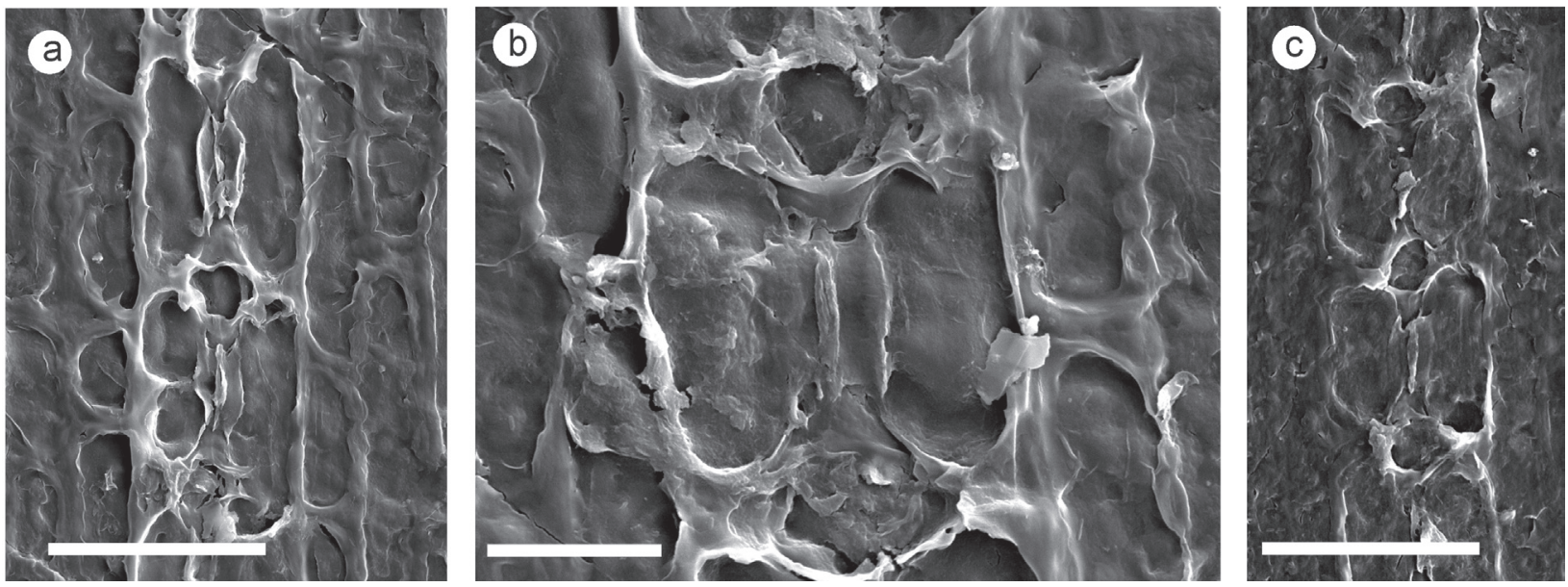

Fig. 9. Cordaites schatzlarensis Šimůnek and Libertín, Makedonka locality, borehole R 95, depth 1822 m, Mogilishte Formation, Duckmantian, SEM images, inner view to abaxial cuticle, stub 29.

a - Two stomata, scale bar $50 \mu \mathrm{m}$,

b - Detail of a stomatal complex, scale bar $20 \mu \mathrm{m}$,

c - Two stomata, scale bar $50 \mu \mathrm{m}$.

Adaxial cuticle (Figs 7c-e, 8d). Cells are not distinguishable between the costal and intercostal areas. They are oblong, 45-100 $\mu \mathrm{m}$ long and 15-30 $\mu \mathrm{m}$ wide, with straight anticlinal walls. Stomata are absent or very rare on the adaxial cuticle; only one stoma has been found (Fig. 7e) over a surface area of $20 \mathrm{~mm}^{2}$. A stoma has been observed also in SEM (Fig. 8d). The guard cells are elliptical, $30 \mu \mathrm{m}$ long and $15 \mu \mathrm{m}$ wide. Polar cells are square to oblong, $30-40 \mu \mathrm{m}$ long and $25-30 \mu \mathrm{m}$ wide. The lateral subsidiary cells are reniform, $50-55 \mu \mathrm{m}$ long and $20-25 \mu \mathrm{m}$ wide, thus the stomatal complex is $120 \mu \mathrm{m}$ long and $70 \mu \mathrm{m}$ wide. The stomatal density varies from $0-1$ stoma per $\mathrm{mm}^{2}$ and the stomatal index from 0 to 0.1 .

Abaxial cuticle (Figs $7 \mathrm{f}-\mathrm{i}, 8 \mathrm{a}, \mathrm{b}, \mathrm{g}-\mathrm{j}$ ). Stomatiferous bands consist of one, exceptionally two, stomatal rows and the cells differ from those of the non-stomatiferous bands. In the stomatiferous band consisting of two stomatal rows, they are mutually separated by a $40-50 \mu \mathrm{m}$ wide non-stomatiferous band and from other stomatal rows by $90-100 \mu \mathrm{m}$ wide non-stomatiferous bands (Figs 7f, g, 8g, h). The non-stomatiferous (costal) bands consist of 3 or 6 rows of oblong, elongated trapezoidal or pentagonal cells, 32-60 $\mu \mathrm{m}$ long and 15-22 $\mu \mathrm{m}$ wide; these cells form regularly alternating bands of different width.

The stomatal complex is formed by a pair of elliptical guard cells, two polar subsidiary cells and two lateral subsidiary cells. The pairs of guard cells have their polar ends formed into a "swallow-tail" shape. They are 18-25 $\mu \mathrm{m}$ long and 10-13 $\mu \mathrm{m}$ wide. The stomatal aperture is $10-13 \mu \mathrm{m}$ long (Fig. 9b). The stomatal complex (including the subsidiary cells) is $50-62 \mu \mathrm{m}$ long and $40-45 \mu \mathrm{m}$ wide. Polar subsidiary cells are rounded in shape (Figs 9a, c). One polar cell is often shared by two neighbouring stomata. Polar cells are usually $10-15 \mu \mathrm{m}$ in diameter. Lateral subsidiary cells are reni- form. Anticlinal walls are bent; the cells are rounded in the corners. Lateral cells are $30-45 \mu \mathrm{m}$ long and 15-22 $\mu \mathrm{m}$ wide. The cuticle viewed from the outer side under SEM is strongly corroded; only prominent stomatal rows (Figs 8i, j) are visible, but not the anticlinal cell walls. The stomatal density is $170-260$ stomata per $1 \mathrm{~mm}^{2}$ of the leaf area. The value of stomatal index varies between 10 and 14 (including the non-stomatiferous bands).

Comparison. Comparison of specimens from Žaclér (Czech Republic) with similar species is made in Šimůnek and Libertín (2006). Comparison of venation is always difficult because, in addition to the state of preservation, it also depends on the position on the leaf (proximal versus distal part) and whether the adaxial or abaxial side is being observed. The thickness of "veins" can vary, making it difficult to distinguish "thick" and "thin" veins, which can hinder their evaluation. Cordaites schatzlarensis from the type area (Žaclér) has 18-36 thick veins per $\mathrm{cm}$ and $1-3$ veins between two thick veins, depending on whether it is being viewed on the adaxial or abaxial side. The sample from the Dobrudzha Basin has 34-40 thick veins per $\mathrm{cm}$ and zero thin veins. These differences can be explained as a result of taphonomy.

Cuticles of Cordaites schatzlarensis specimens from the Duckmantian Substage of Bulgaria resemble those of comparable age from Bohemia. Stomatal complexes of evaluated specimens are practically the same. Important diagnostic features are the small rounded subsidiary cells and swallow-tail polar ends of the guard cells. The dimensions of stomatal complexes of Bulgarian and Czech samples are approximately the same. The differences are in stomatal density: C. schatzlarensis from Bulgaria has 160-250 stomata per $\mathrm{mm}^{2}$, whereas C. schatzlarensis from the Czech Republic has 270-320 stomata per $\mathrm{mm}^{2}$. The stomatal index of samples from both regions is approximately the same $-10-15$. The adaxial cuticles of 
C. schatzlarensis from both regions have very low stomatal densities. In samples from the Czech Republic it varies from 0-40 per $\mathrm{mm}^{2}$, whereas in samples from Bulgaria - only from 0-1. It seemed that Bulgarian samples ware hypostomatic, until a single stoma was discovered.

The most similar species to Cordaites schatzlarensis with respect to cuticles is probably Cordaites baodeensis Ge from the Permian of China. It is also amphistomatic with a low stomatal density on the adaxial cuticle, and the stomatal complexes on the abaxial cuticle are of the same shape and dimensions. Ge (1991) did not mentioned the "swallow-tail" projections at the polar ends of guard cells of Cordaites baodeensis, however, this feature is visible on some SEM images of C. baodeensis. C. baodeensis has a stomatal density of 256 stomata per $\mathrm{mm}^{2}$, which also fits within the range of $C$. schatzlarensis. The main difference is in the venation: $C$. baodeensis has 3-6 thin veins between two thick veins, much more than in C. schatzlarensis.

Also similar is Cordaites "anguloso-striatus” Grand 'Eury from the Bolsovian of the Ruhr Basin, Germany, described by Rabitz (1966). The abaxial cuticle (shown as a drawing by Rabitz, 1966, fig. 2) also has reniform lateral subsidiary cells and small rounded polar subsidiary cells. Stomata are arranged into stomatal rows, and are as dense as in Cordaites schatzlarensis or Cordaites baodeensis. The guard cells do not have the characteristic swallow-tail shape projections. These features are not seen in photographs of low magnification. It seems that stomatiferous bands are present. The adaxial cuticle is formed by oblong cells without stomata.

\section{Cordaites of the Bolsovian (Westphalian C) Substage}

\section{Cordaites makedonkanus Šimůnek and Tenchov sp. nov. (Figs 10, 11)}

Holotype: Here designated (Fig. 11a), Czech Geological Survey, Prague, inv. No. ZŠ 455, coll. Y. Tenchov (orig. No. 13409).
Derivation of name: After Makedonka village.

Type locality: Makedonka, borehole R 160, depth 1385 m. Type horizon: Makedonka Formation, Westphalian Stage, middle Bolsovian Substage (Moscovian Stage).

Material: Slides 409/1-2.

Diagnosis: Moderately wide, amphistomatic leaves with infrequent venation. One thick vein alternates with 1-3 thin veins. Adaxial and abaxial cells are more or less oblong. Stomatal complexes on adaxial cuticle arranged in dark stomatal rows of uneven distance. Lateral subsidiary cells reniform to oval. Stomatal complexes of abaxial cuticle in stomatal rows. Lateral subsidiary cells reniform to oblong.

Description of holotype. The leaf fragment for maceration is $35 \mathrm{~mm}$ long, with incomplete width of at least $25 \mathrm{~mm}$. It was hidden beneath other leaves. The venation density is about 14 veins per $\mathrm{mm}$. There are one to three thin veins for every thick vein (Fig. 11b). The thick veins are usually very prominent.

The cells of the adaxial cuticle (Figs 10b, 11e, f) are distinguished into double dark rows separated by nonstomatiferous bands, 150-160 $\mu \mathrm{m}$ wide. Each row, 70$75 \mu \mathrm{m}$ wide, is separated by a line of cells about $25 \mu \mathrm{m}$ wide, so that the doubled rows are about $175 \mu \mathrm{m}$ wide. The cells of the light non-stomatiferous bands are oblong, 40-75 $\mu \mathrm{m}$ long and 15-30 $\mu \mathrm{m}$ wide. The cells of dark rows are small, oblong, 20-50 $\mu \mathrm{m}$ long and 15-20 $\mu \mathrm{m}$ wide. The anticlinal walls are straight or slightly bent. Due to their dark colour, the stomata are barely visible in photographs. They can be drawn using a Camera Lucida drawing attachment for comparison (Fig. 10b). The stomatal complex is relatively small, formed by elliptical, sunken guard cells, $18-24 \mu \mathrm{m}$ long and 8-10 $\mu \mathrm{m}$ wide. One stomatal complex consists of 2 guard cells, 2 lateral and 2 polar subsidiary cells. The lateral cells are oval, relatively wide (30-35 $\mu \mathrm{m}$ long and 15-20 $\mu \mathrm{m}$ wide), the polar cells are small, elliptical, or elongated oblong, 18-35 $\mu \mathrm{m}$ long and 10-15 $\mu \mathrm{m}$ wide (Fig. 10b). The stomatal density is $125-150$ stomata per $\mathrm{mm}^{2}$, the stomatal index is 5 .

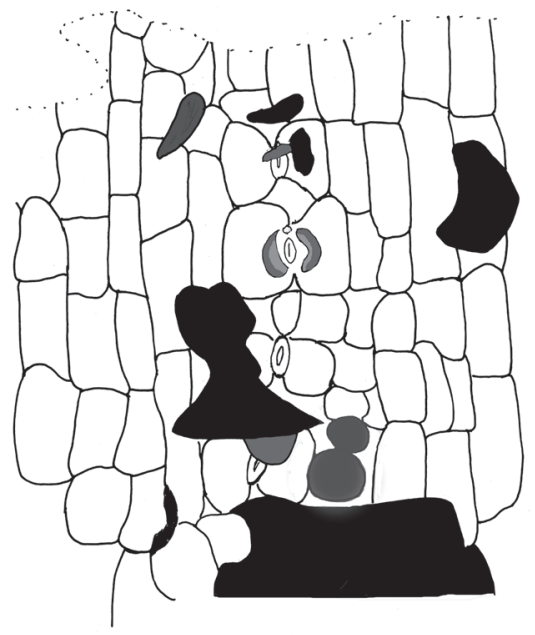

a

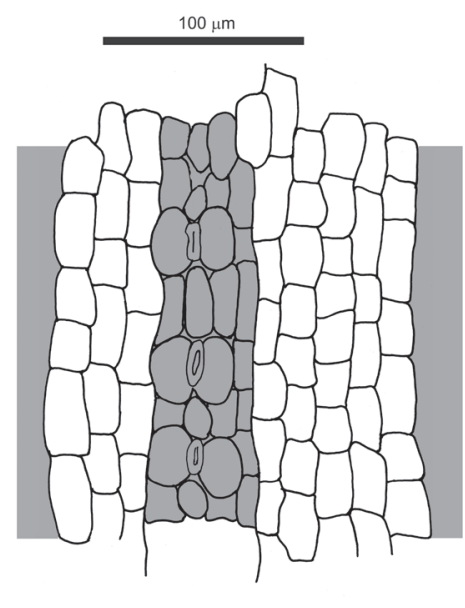

b

Fig. 10. Cordaites makedonkanus Šimůnek and Tenchov sp. nov.

a - Abaxial cuticle with a stomatal row. Grey and black spots are undissolved matter between cuticles, slide 409/2 (Fig. 11d); b - Adaxial cuticle with stomata in dark rows, slide 409/1. Scale bar $100 \mu \mathrm{m}$. 

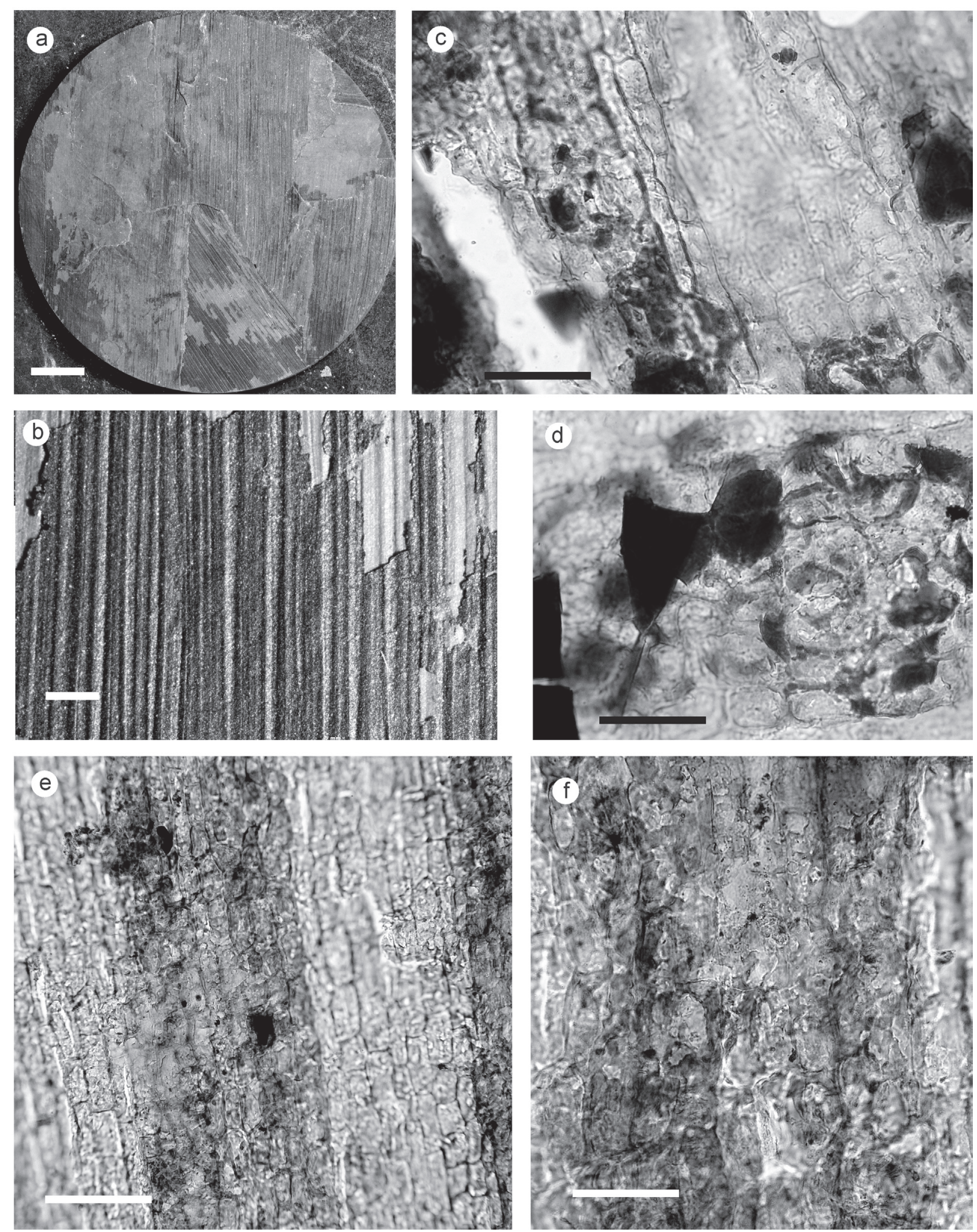

Fig. 11. Cordaites makedonkanus Šimůnek and Tenchov sp. nov., Makedonka locality, borehole R 160, depth 1385 m, Makedonka Formation, middle Bolsovian .

a - Leaf fragment No. ZS 455 (orig. no. 13409), scale bar $1 \mathrm{~cm}$;

$\mathrm{b}$ - Venation detail from Fig. 11a, scale bar $1 \mathrm{~mm}$;

c - Abaxial cuticle with two stomatal rows, slide 409/2, scale bar $50 \mu \mathrm{m}$;

d - Close up of stomatal row of abaxial cuticle with a stomatal complex, slide 409/2, scale bar $50 \mu \mathrm{m}$;

e - Adaxial cuticle with stomatal rows, slide 412/7, scale bar $100 \mu \mathrm{m}$;

$\mathrm{f}-$ Close up of two stomatal rows from Fig. 11e, scale bar $50 \mu \mathrm{m}$. 
The cells on the abaxial cuticle are differentiated into stomatal rows and non-stomatiferous bands (Figs 10a, $11 \mathrm{c}, \mathrm{d})$. The cells of non-stomatiferous bands are oblong, $38-70 \mu \mathrm{m}$ long and $12-26 \mu \mathrm{m}$ wide. The stomatal rows comprise only stomatal complexes and small cells. These cells are oblong, square, oval or circular, usually only 20-35 $\mu \mathrm{m}$ long and 10-20 $\mu \mathrm{m}$ wide. The anticlinal walls are bent. The guard cells are wide, elliptical, 15-20 $\mu \mathrm{m}$ long and $8-10 \mu \mathrm{m}$ wide. The polar subsidiary cells are small, irregular, square or circular, 20-25 $\mu \mathrm{m}$ in diameter. The lateral subsidiary cells are mostly oblong to reniform, 35-55 $\mu \mathrm{m}$ long and 20-25 $\mu \mathrm{m}$ wide. The crypt is not developed. Stomatal density is about 125 stomata per $\mathrm{mm}^{2}$. The stomatal index is 7 .

Comparison. The problem with comparing cuticles of Cordaites makedonkanus is that they are not perfectly preserved. The stomatal complexes on the abaxial cuticle are arranged into stomatal rows, and they are very wide because the lateral subsidiary cells are wide and oblong. Cordaites rerichensis Šimůnek, Cordaites pilsensis Šimůnek and Cordaites krasovicensis Šimůnek (Šimůnek, 2007) also have relatively wide stomatal complexes, but differently shaped lateral subsidiary cells: C. rerichensis - wide reniform, C. pilsensis and C. krasovicensis - trapezoidal. Stomata on the adaxial cuticle are arranged into dark stomatal rows. This feature also occurs in Cordaites melnicensis Šimůnek and Cordaites wartmannii Šimůnek (Šimůnek, 2007), but both have stomata on the abaxial cuticle arranged into stomatiferous bands. Other species herein described as Cordaites cf. melnicensis and Cordaites gurkovoensis have similar patterns of adaxial cuticle.

\section{Cordaites dobrudzhanus Šimůnek and Tenchov sp. nov. (Figs 12, 13)}

Holotype: Here designated (Fig. 12a), Czech Geological Survey, Prague, inv. No. ZS 456, coll. Y. Tenchov (orig. No. 7605)
Derivation of name: After the Dobrudzha Basin.

Type locality: Makedonka, borehole R 94, depth 1649 m. Type horizon: Makedonka Formation, Pennsylvanian Subsystem, Westphalian Stage, Bolsovian Substage (Moscovian Stage).

Material: Slides 534/1-9.

Diagnosis: Medium wide amphistomatic leaves with infrequent venation; 3-6 thin veins alternate with each thick vein. Ordinary cells of adaxial and abaxial cuticles are oblong. Stomatal complexes of adaxial and abaxial cuticles arranged into stomatal rows. Stomatal complexes of adaxial cuticle narrow, of abaxial cuticle wide. Lateral subsidiary cells in both cuticles oblong to reniform.

Description of holotype. The leaf fragment is $90 \mathrm{~mm}$ long and approximately $40 \mathrm{~mm}$ wide. It is difficult to estimate its dimensions because it is covered by other leaves. The venation density is $12-16$ veins per $\mathrm{mm}$. Three to six thin veins alternate with one thick vein (Fig. 13b). The thick veins are just slightly thicker than the 'thin' veins, and are sometimes hardly distinguishable.

The adaxial cuticle (Figs 12b, 13c, e, f) is differentiated into stomatal rows and non-stomatiferous bands. Stomatal rows are relatively narrow - stomatal complexes are 50-60 $\mu \mathrm{m}$ long and 30-35 $\mu \mathrm{m}$ wide. The cells of the non-stomatiferous band are oblong, 26-80 $\mu \mathrm{m}$ long and $10-16 \mu \mathrm{m}$ wide. Each stomatal complex is formed by 2 guard cells, 2 polar subsidiary cells and 2 lateral subsidiary cells. The guard cells are sunken, 20-25 $\mu \mathrm{m}$ long and 7-14 $\mu \mathrm{m}$ wide. The polar subsidiary cells are irregular, 10-20 $\mu \mathrm{m}$ long and 5-15 $\mu \mathrm{m}$ wide. The lateral subsidiary cells are oblong, 35-55 $\mu \mathrm{m}$ long and 12-15 $\mu \mathrm{m}$ wide. Stomatal density is about 170 stomata per $\mathrm{mm}^{2}$. The stomatal index is 11 .

The abaxial cuticle (Figs 12a, 13d) is formed by stomatiferous and non-stomatiferous bands. The non-stomatiferous bands are formed by oblong cells, 30-65 $\mu \mathrm{m}$ long and 10-15 $\mu \mathrm{m}$ wide. The stomatiferous band, up to $150 \mu \mathrm{m}$ wide, consists of up to 3 stomatal rows separated by a single row of cells. Stomatal complexes are 60-70 $\mu \mathrm{m}$

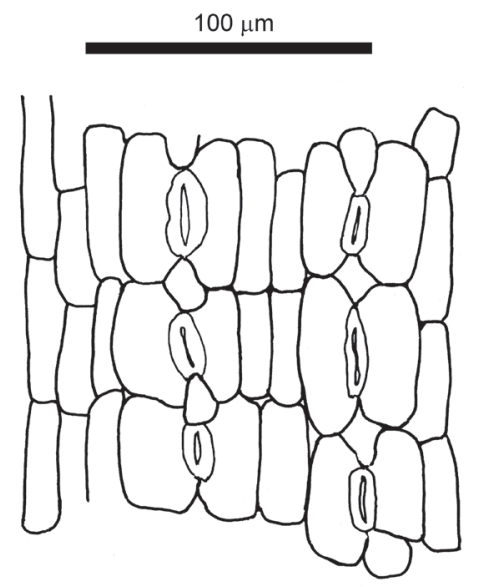

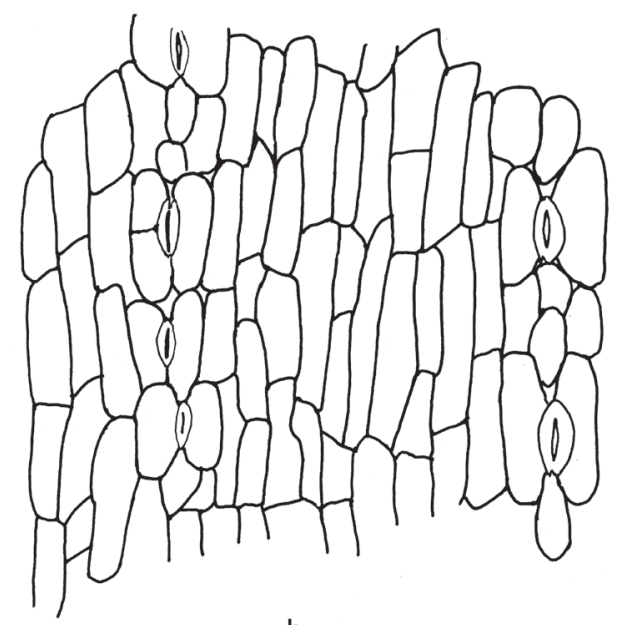

b

Fig. 12. Cordaites dobrudzhanus Šimůnek and Tenchov sp. nov. a - Abaxial cuticle with stomatal rows, slide 534/4,

b - Adaxial cuticle with stomatal rows, slide 534/9. Scale bar $100 \mu \mathrm{m}$. 

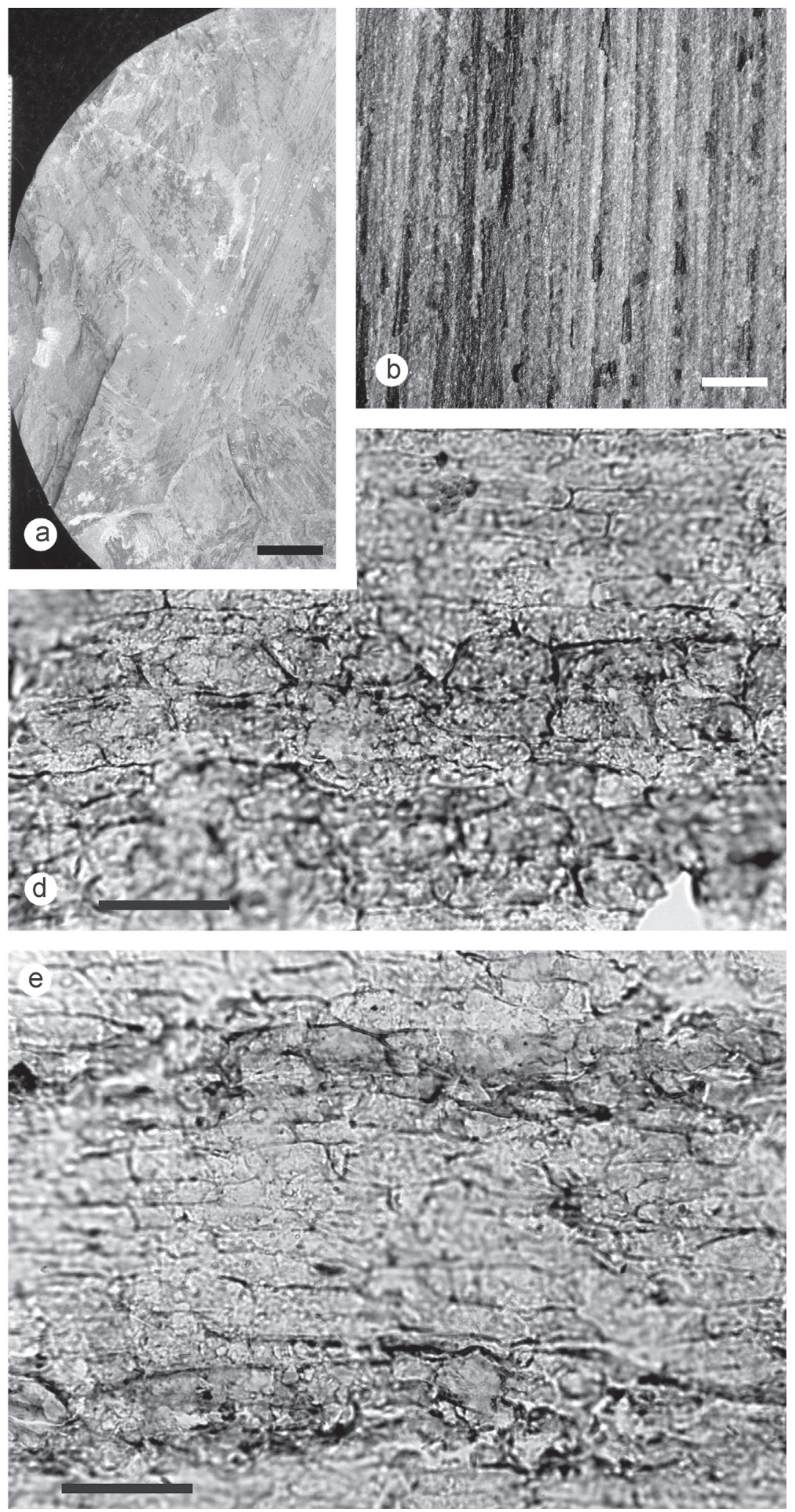
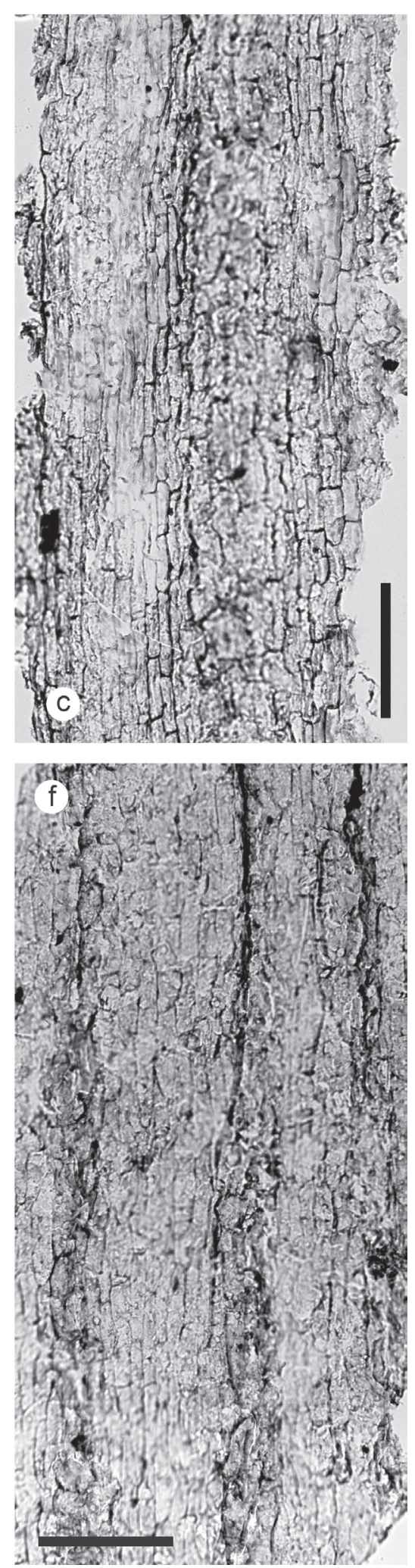

Fig. 13. Cordaites dobrudzhanus Šimůnek and Tenchov sp. nov., Makedonka locality, borehole R 94, depth 1649 m, Makedonka Formation, Bolsovian.

a - Leaf fragment No. ZŠ 456 (orig. no. 7605), scale bar $1 \mathrm{~cm}$;

b - Venation detail from Fig. 13a, scale bar $1 \mathrm{~mm}$;

c - Adaxial cuticle with three stomatal rows, slide 534/7, scale bar $100 \mu \mathrm{m}$;

$\mathrm{d}$ - Close up of two stomatal rows of abaxial cuticle, slide 534/4, scale bar $50 \mu \mathrm{m}$;

e - Adaxial cuticle with two stomatal rows, a detail from Fig. 13f, slide 534/8, scale bar $50 \mu \mathrm{m}$;

$\mathrm{f}$ - Adaxial cuticle with three stomatal rows, scale bar $100 \mu \mathrm{m}$. 
long and 40-50 $\mu \mathrm{m}$ wide. The sunken guard cells are elliptical, 20-25 $\mu \mathrm{m}$ long and 10-14 $\mu \mathrm{m}$ wide. The polar subsidiary cells are oval or irregular, nearly isodiametric 15-25 $\mu \mathrm{m}$ long and 8-12 $\mu \mathrm{m}$ wide. The lateral subsidiary cells are usually oblong, 35-55 $\mu \mathrm{m}$ long and 15-22 $\mu \mathrm{m}$ wide. Stomatal density is about 200 stomata per $\mathrm{mm}^{2}$. The stomatal index is 10 .

Comparison. Cordaites dobrudzhanus has stomatal complexes on both adaxial and abaxial cuticles arranged into stomatal rows. These rows are separated by only 1-2 cell rows and form "stomatiferous bands" separated by wide non-stomatiferous bands. Cordaites species from Bohemia with stomatifersous bands typically have stomatal rows in contact, without simple cell rows (Šimůnek, 2007). Cordaites dobrudzhanus is most similar to Cordaites principalis Type 2 of Zodrow et al. (2000) from the Bolsovian of Bay St. George, Newfoundland, Canada, which also has stomata on the adaxial and abaxial cuticles in stomatal rows. However, the distance between stomatal rows on the abaxial cuticle is much greater in the Canadian species than in C. dobrudzhanus.

Remarks. A difficulty exists with the assignment of Cordaites dobrudzhanus to the Cordaites cuticular groups. This species has stomatal rows separated by single or double cell rows. According to a strict definition it should be classified to Type B. However, C. dobrudzhanus has "sets" of stomatal rows that are separated by wide, non-stomatiferous bands, thus better corresponding to the Type $\mathrm{C}$ cuticles.

\section{Cordaites of the Asturian (Westphanian D) Substage}

\section{Cordaites cf. melnicensis Šimůnek (Figs. 14-16)}

cf. 2007 Cordaites melnicensis Šimůnek, p. 139-140, fig. 34, pl. 35, figs. 4-6, pl. 36, 37, figs. $1-7$.

Material: Two specimens from the Makedonka locality, borehole R 57, depths 1516 and 1372 m, Gurkovo Formation, Asturian, specimens Nos. ZS 457 and 458 (orig. Nos. 5790, 5590) and slides 533/1-9; 532/1-3.

Description of hand specimens (Figs 14a, c). The leaf fragments are as long as the core diameter $-85 \mathrm{~mm}$. The width is $38 \mathrm{~mm}$ (Fig. 14a) to $42 \mathrm{~mm}$ (Fig. 14c). Leaf margins are parallel. The venation is sparse $-14-18$ veins per mm; 1-3 thin veins alternate with each thick vein (Figs 14b, d). The thick veins are relatively thin, whereas "thin" veins are relatively thick, and in places are barely distinguishable (Fig. 14b). Small transverse wrinkles are observable between the veins (Fig. 14d).

The adaxial cuticle consists of dark stomatal rows, irregularly 150-260 $\mu \mathrm{m}$ apart, and non-stomatiferous (costal) bands (Fig. 14f). The costal cells are oblong, 35-75 $\mu \mathrm{m}$ long and 12-30 $\mu \mathrm{m}$ wide. The ordinary cells of the stomatal rows are also oblong, but smaller than the costal cells - 35-65 $\mu \mathrm{m}$ long and 10-15 $\mu \mathrm{m}$ wide. Anticlinal walls are bent or more or less straight. Stomata are sparsely distributed in dark rows. The guard cells are elliptical, 15-25 $\mu \mathrm{m}$ long and 8-14 $\mu \mathrm{m}$ wide. Polar subsidiary cells are oval, 20-30 $\mu \mathrm{m}$ long and 10-15 $\mu \mathrm{m}$ wide. Lateral subsidiary cells are reniform or oval, 35-40 $\mu \mathrm{m}$ long and 15-20 $\mu \mathrm{m}$ wide. Each sto- matal complex is 55-95 $\mu \mathrm{m}$ long and 40-55 $\mu \mathrm{m}$ wide. The crypt above the guard cells is oblong with concave cell walls (Fig. 14g), and in some cases nearly closes the aperture of the epistomatal chamber (Figs 14g, 15b, c, f). Stomatal density varies from 25 to 45 stomata per $\mathrm{mm}^{2}$ and stomatal index from 3 to 4 .

The abaxial cuticle is differentiated into stomatal rows and non-stomatiferous bands (Fig. 15d). The cells of the non-stomatiferous bands are oblong, 30-75 $\mu \mathrm{m}$ long and 10-25 $\mu \mathrm{m}$ wide. The ordinary cells of stomatal rows are also oblong but dark, $20-40 \mu \mathrm{m}$ long and 10-15 $\mu \mathrm{m}$. The guard cells are elliptical, about $20 \mu \mathrm{m}$ long and $5 \mu \mathrm{m}$ wide. The polar subsidiary cells are oblong to oval, 20-25 $\mu \mathrm{m}$ long and $12-16 \mu \mathrm{m}$ wide. Lateral subsidiary cells are trapezoidal to reniform, 30-45 $\mu \mathrm{m}$ long and 14-18 $\mu \mathrm{m}$ wide. The stomatal complex is $60-75 \mu \mathrm{m}$ long and $40-45 \mu \mathrm{m}$ wide. The crypt is not prominent. It is difficult to estimate stomatal index and stomatal density from the small fragment available. The stomatal density is estimated to be 90-110 stomata per $\mathrm{mm}^{2}$ and stomatal index to 6-7.

Comparison. Bulgarian and Bohemian samples of Cordaites melnicensis have approximately the same vein densities: that from Bulgaria - 14-18 thick veins per cm; that from Bohemia -12-14 thick veins per $\mathrm{cm}$. In Bulgarian samples, 1-3 thin veins alternate with each thick vein, in the Bohemian samples there are 3-5 thin veins between two thick veins. The Bulgarian samples come from the Asturian, whereas the Bohemian samples are from the Stephanian B.

The adaxial cuticles of samples from both regions are practically the same. The stomata are arranged into dark stomatal rows spaced at uneven distances. The stomatal complexes in the abaxial cuticles of the Bohemian samples are in stomatiferous bands, whereas those in the Bulgarian samples are in stomatal rows. The abaxial cuticle is weakly cutinised, and only a small fragment was found in the Bulgarian specimens. The shape of the stomatal complexes from both regions is approximately the same. The adaxial cuticle of Bulgarian samples with a single stomatal row may come from near the leaf margin, where stomatiferous bands are not typically developed and often single stomatal rows occur. The same type of adaxial cuticle with dark stomatal rows occurs in C. makedonkanus and C. gurkovoensis.

Remarks. Only a small fragment of abaxial cuticle of Cordaites cf. melnicensis with a stomatal row has been preserved (Fig. 15d). Such a feature is characteristic of Type $\mathrm{B}$, whereas this species in the Bohemian Massif belongs to Type C. It is maybe the case that single stomatal rows occur among stomatiferous bands typical for the Type C.

\section{Cordaites vraninoensis Šimůnek and Tenchov sp. nov. (Figs 17-19)}

Holotype: Here designated (Fig. 17a), Czech Geological Survey, Prague, inv. No. Z ̌ 459, coll. Y. Tenchov (orig. No.12866)

Derivation of name: After Vranino village.

Type locality: Vranino locality, borehole R 139, depth $1594 \mathrm{~m}$

Type horizon: Gurkovo Formation, Asturian Substage (Moscovian Stage). 

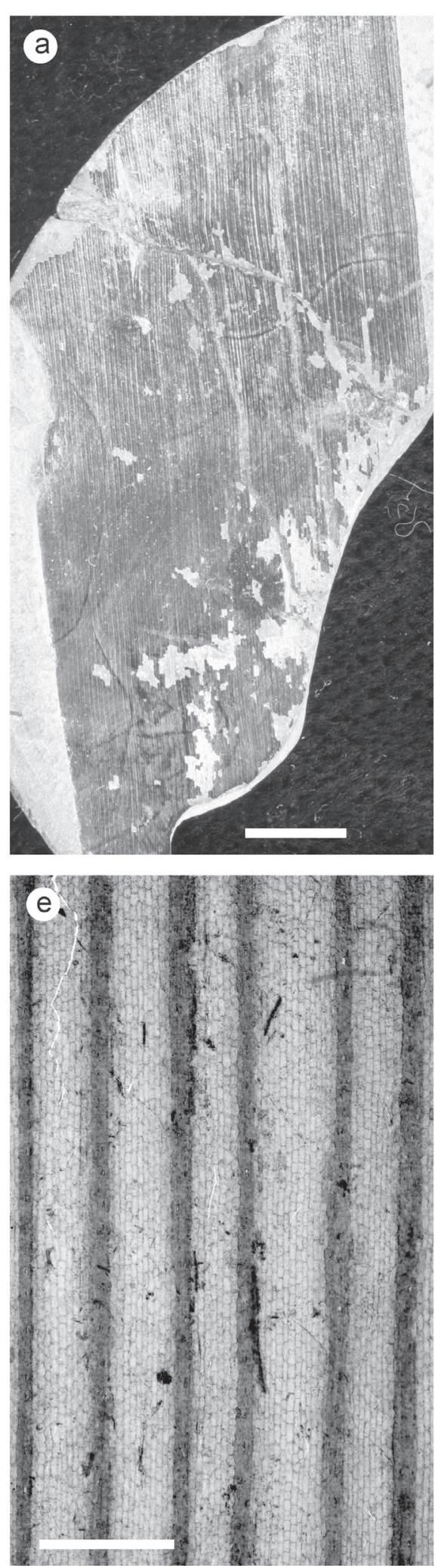
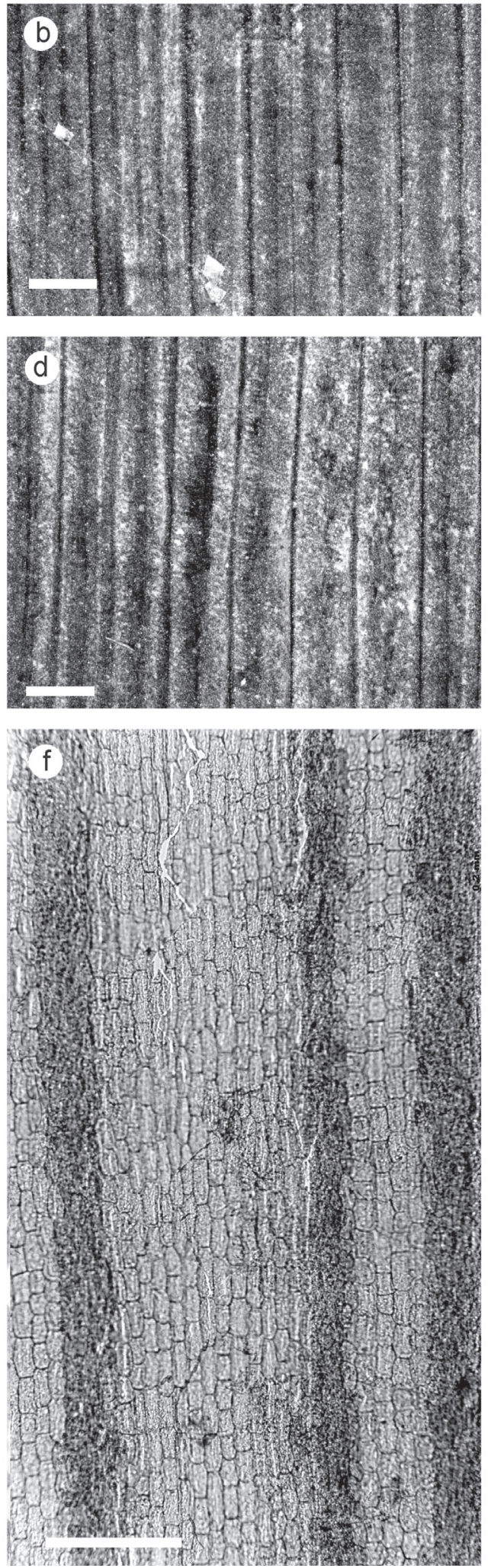
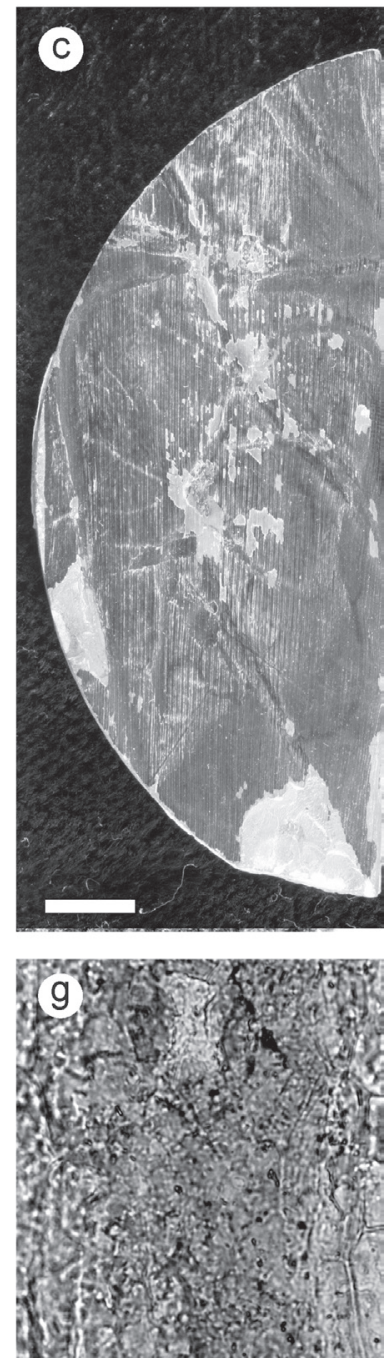

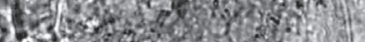

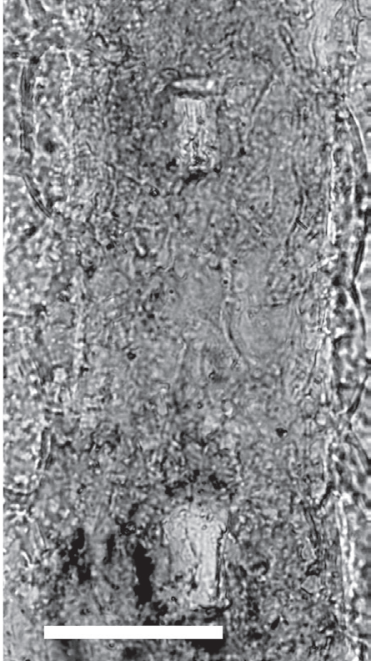

Fig. 14. Cordaites cf. melnicensis Šimůnek., Makedonka locality, Gurkovo Formation, Asturian.

a - Leaf fragment No. ZŠ 457 (orig. no. 5590), borehole R 57, depth 1516 m, material to slides 532/1-3, scale bar $1 \mathrm{~cm}$; b - Venation detail from Fig. 14a, scale bar $1 \mathrm{~mm}$;

c - Leaf fragment No. ZЉ 458 (orig. no. 5790), borehole R 57, depth 1372 m, material to slides 533/1-9, scale bar $1 \mathrm{~cm}$; $\mathrm{d}-$ Venation detail from Fig. 14c, scale bar $1 \mathrm{~mm}$;

e - Adaxial cuticle with dark stomatal rows, slide 533/3, scale bar $500 \mu \mathrm{m}$;

$\mathrm{f}$ - Close up of adaxial cuticle with different distances of dark stomatal rows, slide 533/1, scale bar $100 \mu \mathrm{m}$; $\mathrm{g}$ - Close up of the dark stomatal row with three stomatal complexes, slide 533/1, scale bar $50 \mu \mathrm{m}$. 

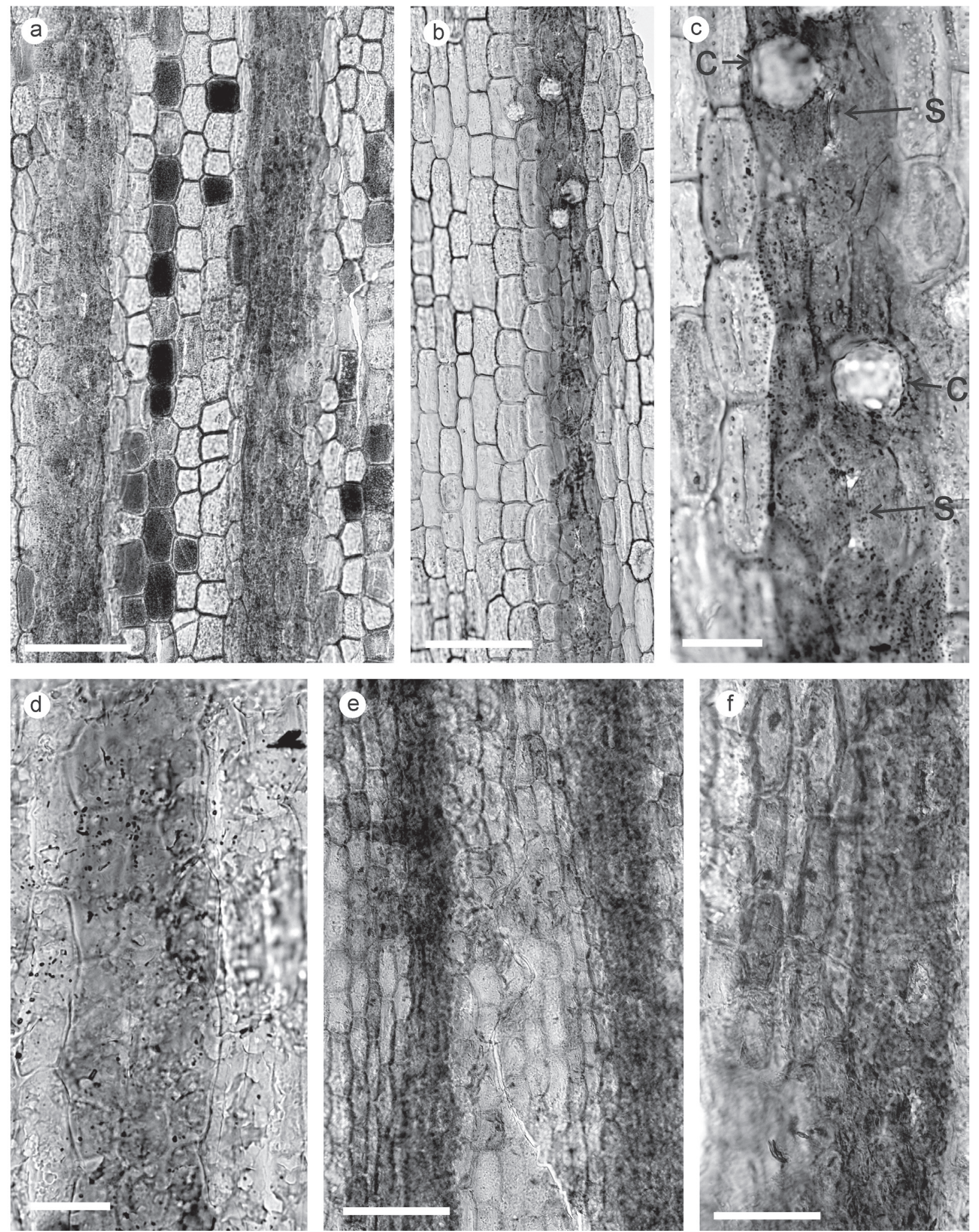

Fig. 15. Cordaites cf. melnicensis Šimůnek., Makedonka locality, Gurkovo Formation, Asturian.

a - Adaxial cuticle with two stomatal rows, some cells coloured after staining, slide 533/7, scale bar $100 \mu \mathrm{m}$;

b - Adaxial cuticle with a stomatal row, circular structures after bacterial or fungal infection, slide 533/4, scale bar $100 \mu$ m;

c-Close up of stomatal row from Fig. 15b with two stomatal complexes (s) and circular structures after bacterial or fungal infection, scale bar $25 \mu \mathrm{m}$;

$\mathrm{d}$ - Abaxial cuticle with stomatal row, the cuticle is very weakly cutinised and cells are more elongated than in the case of adaxial cuticle, slide $533 / 6$, scale bar $25 \mu \mathrm{m}$;

e - Adaxial cuticle with two dark stomatal rows, slide 532/2, scale bar $100 \mu \mathrm{m}$;

$\mathrm{f}$ - Close up of the stomatal row with two stomata from Fig. 15e, scale bar $25 \mu \mathrm{m}$. 

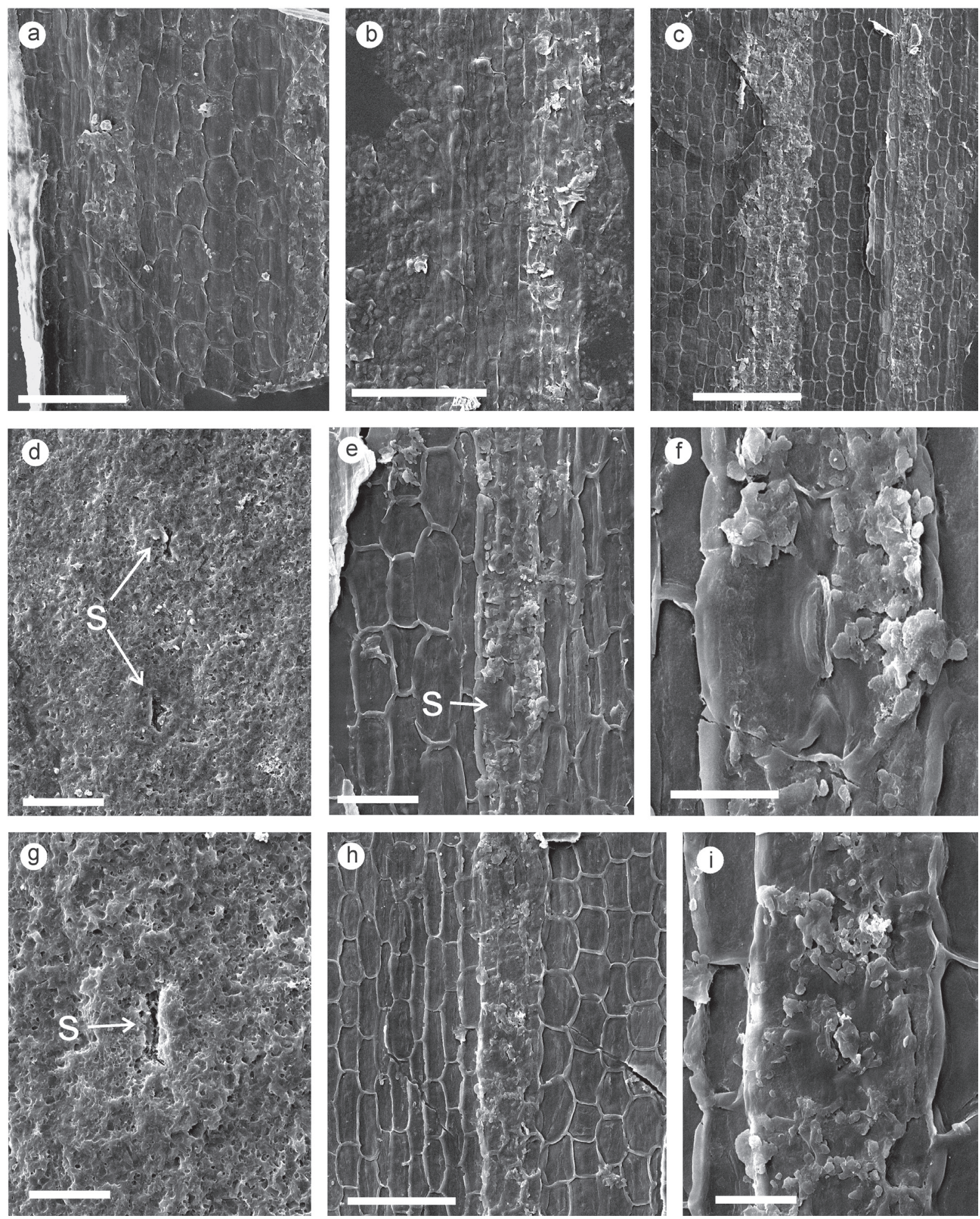

Fig. 16. Cordaites cf. melnicensis Šimůnek, Makedonka locality, Gurkovo Formation, Westphalian D, SEM images, a and b from Fig. 14a, stub 59; c-i from Fig. 14c, stub 59.

a - Inner view to adaxial cuticle with two obscure stomatal rows, scale bar $100 \mu \mathrm{m}$;

$\mathrm{b}$ - Probably inner view to abaxial cuticle with somewhat obscure stomatal row, scale bar $100 \mu \mathrm{m}$;

c - Inner view to adaxial cuticle with two prominent stomatal rows, scale bar $200 \mu \mathrm{m}$;

$\mathrm{d}$ - Outer view to the adaxial cuticle with two prominent stomatal openings (s), scale bar $50 \mu \mathrm{m}$;

$\mathrm{e}$ - Inner view to the adaxial cuticle with prominent stomatal row showing a stomatal complex (s), scale bar $50 \mu \mathrm{m}$;

$\mathrm{f}$ - Detail of the stomatal complex from Fig. 16e, scale bar $20 \mu \mathrm{m}$;

$\mathrm{g}$ - Close up of outer view to the adaxial cuticle with a stomatal opening (s), scale bar $25 \mu \mathrm{m}$;

$\mathrm{h}$ - Inner view to the adaxial cuticle with prominent stomatal row, scale bar $100 \mu \mathrm{m}$;

$\mathrm{i}$ - Detail of the stomatal row from Fig. 16h showing obscure stomatal complex, scale bar $25 \mu \mathrm{m}$; 

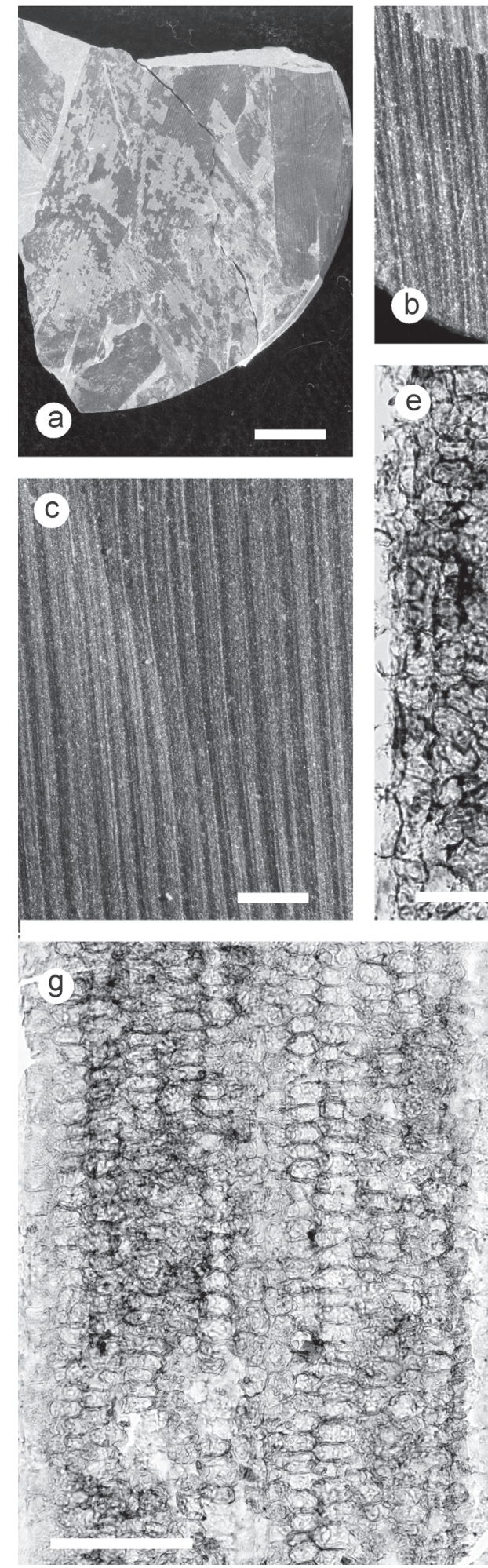
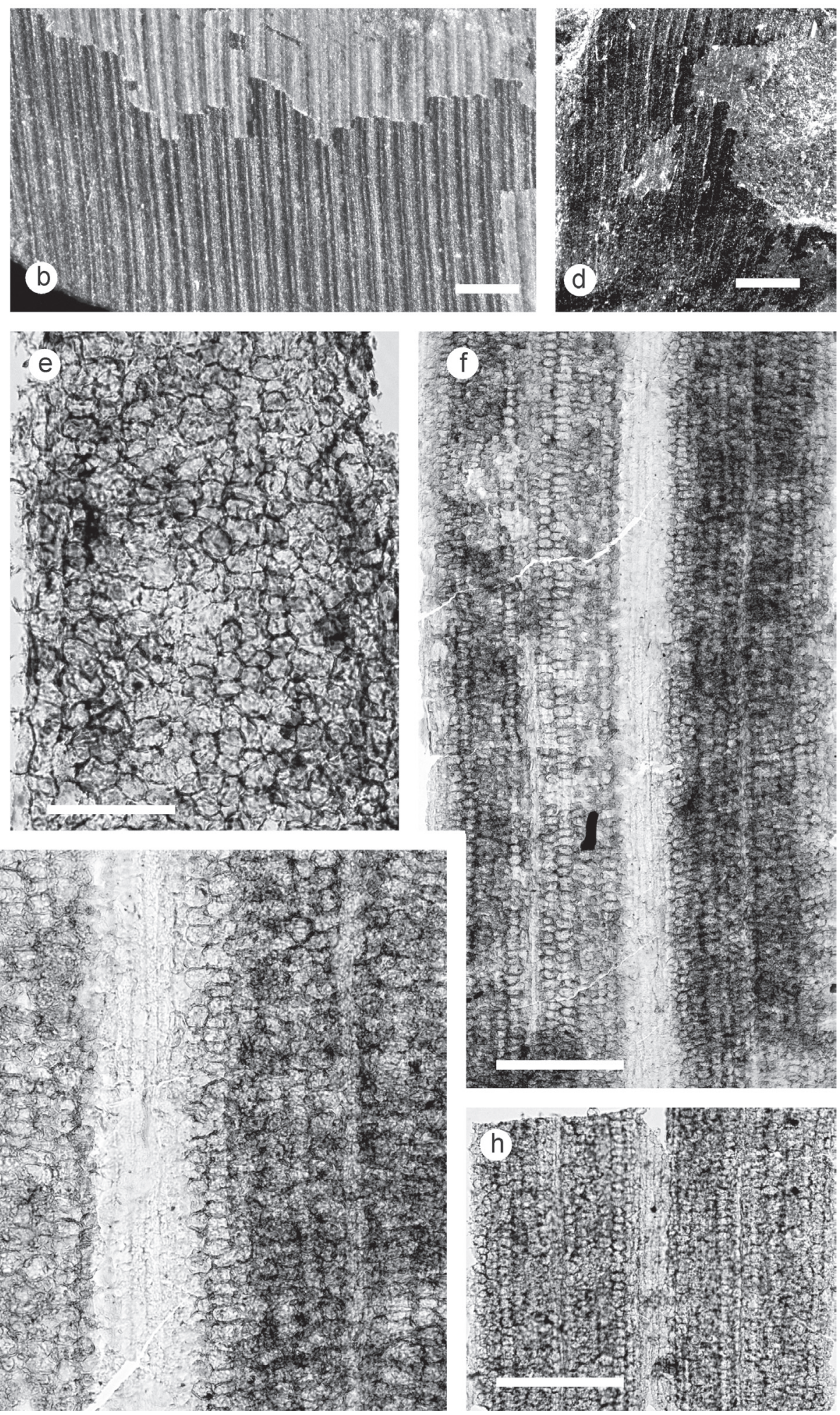

Fig. 17. Cordaites vraninoensis Šimůnek and Tenchov sp. nov.

a - Leaf fragment No. ZŠ 459 (orig. no. 12866), Vranino locality, borehole R 139, depth 1594 m, Gurkovo Formation, Asturian, material to slides 538/1-21, scale bar $1 \mathrm{~cm}$;

b, c - venation from different parts of the blade on Fig. 17a, scale bar $1 \mathrm{~mm}$;

d - Venation of leaf No. ZS 460 (orig. no. 12048), Makedonka locality, borehole R 131, depth 1503 m, Krupen Formation,

Westphalian C/D, and slides 536/1-12, scale bar $1 \mathrm{~mm}$;

e-Subepidermal tissue preserved, slide 536/11, scale bar $100 \mu \mathrm{m}$,

f - Cuticle with preserved subepidermal sclerenchymatic tissue, slide 538/13, scale bar $200 \mu \mathrm{m}$;

$\mathrm{g}$ - Detail of sclerenchymatic tissue from Fig. 17f, scale bar $100 \mu \mathrm{m}$;

$\mathrm{h}$ - Subepidermal sclerenchymatic tissue, slide 536/1, scale bar $200 \mu \mathrm{m}$. 

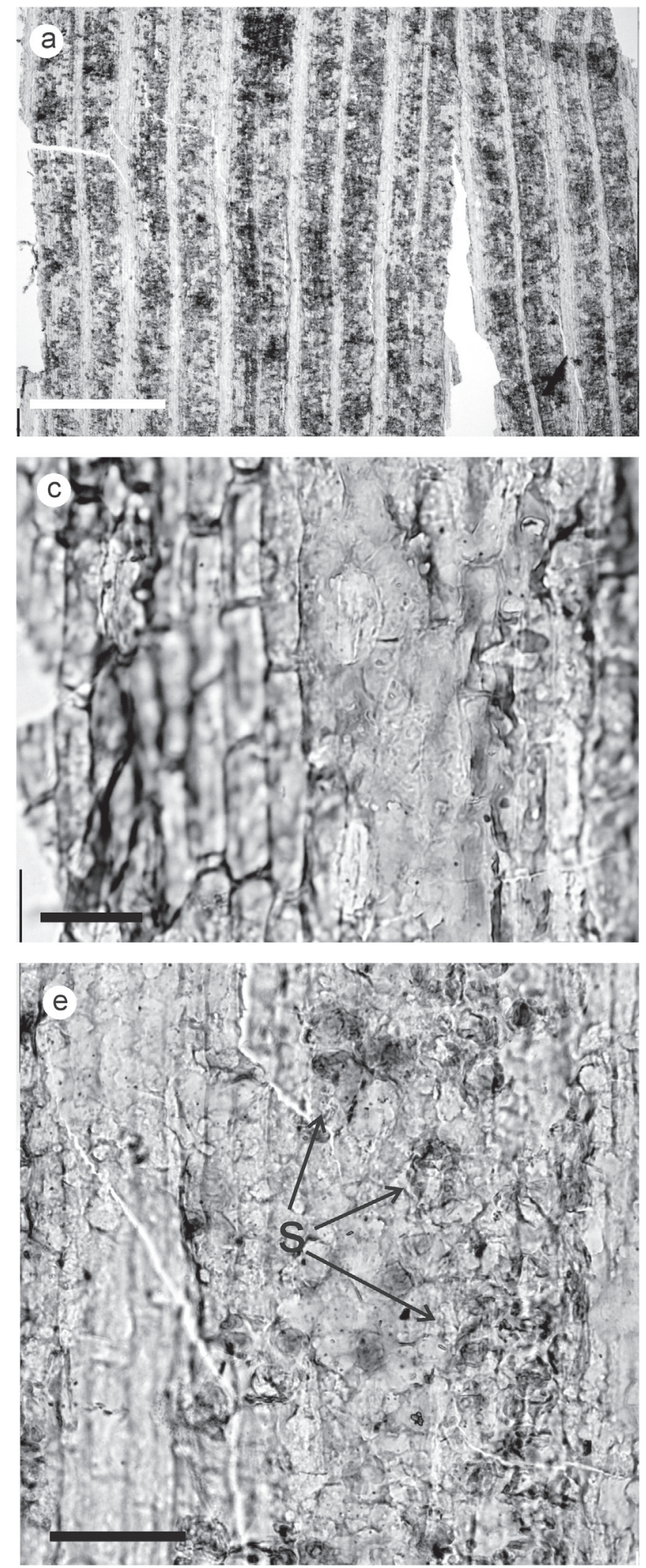
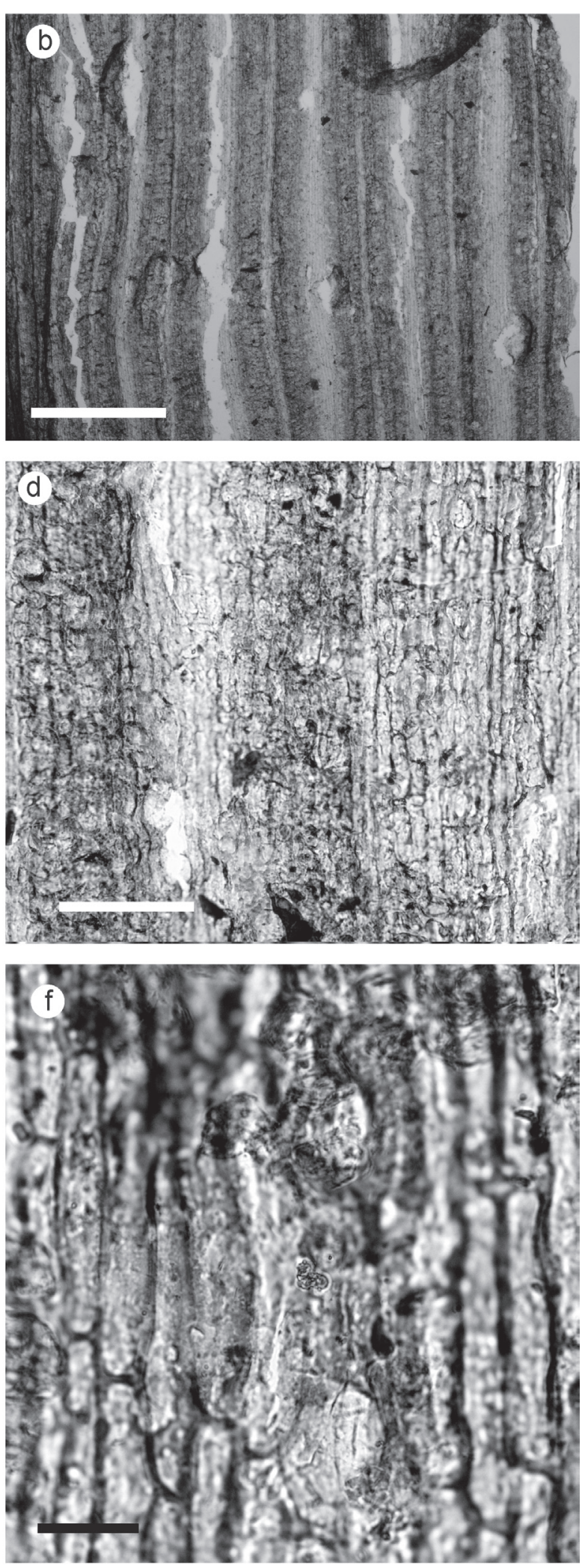

Fig. 18. Cordaites vraninoensis Šimůnek and Tenchov sp. nov., cuticles from Vranino and Krupen localities (see Fig. 17) a - Abaxial cuticle with course of veins and sclerenchymatous strips, slide 536/3, scale bar $500 \mu \mathrm{m}$;

b - (Adaxial?) cuticle with course of veins and sclerenchymatous strips, slide 538/14, scale bar $500 \mu \mathrm{m}$;

c - Adaxial cuticle with two stomata, slide 536/4, scale bar $25 \mu \mathrm{m}$;

d - Adaxial cuticle with two dark stomatal rows, slide 538/17, scale bar $100 \mu \mathrm{m}$;

e - Abaxial cuticle with stomata (s) in stomatiferous band, slide 536/3, scale bar $50 \mu \mathrm{m}$;

f - Adaxial cuticle with two stomata, slide 538/17, scale bar $25 \mu \mathrm{m}$. 

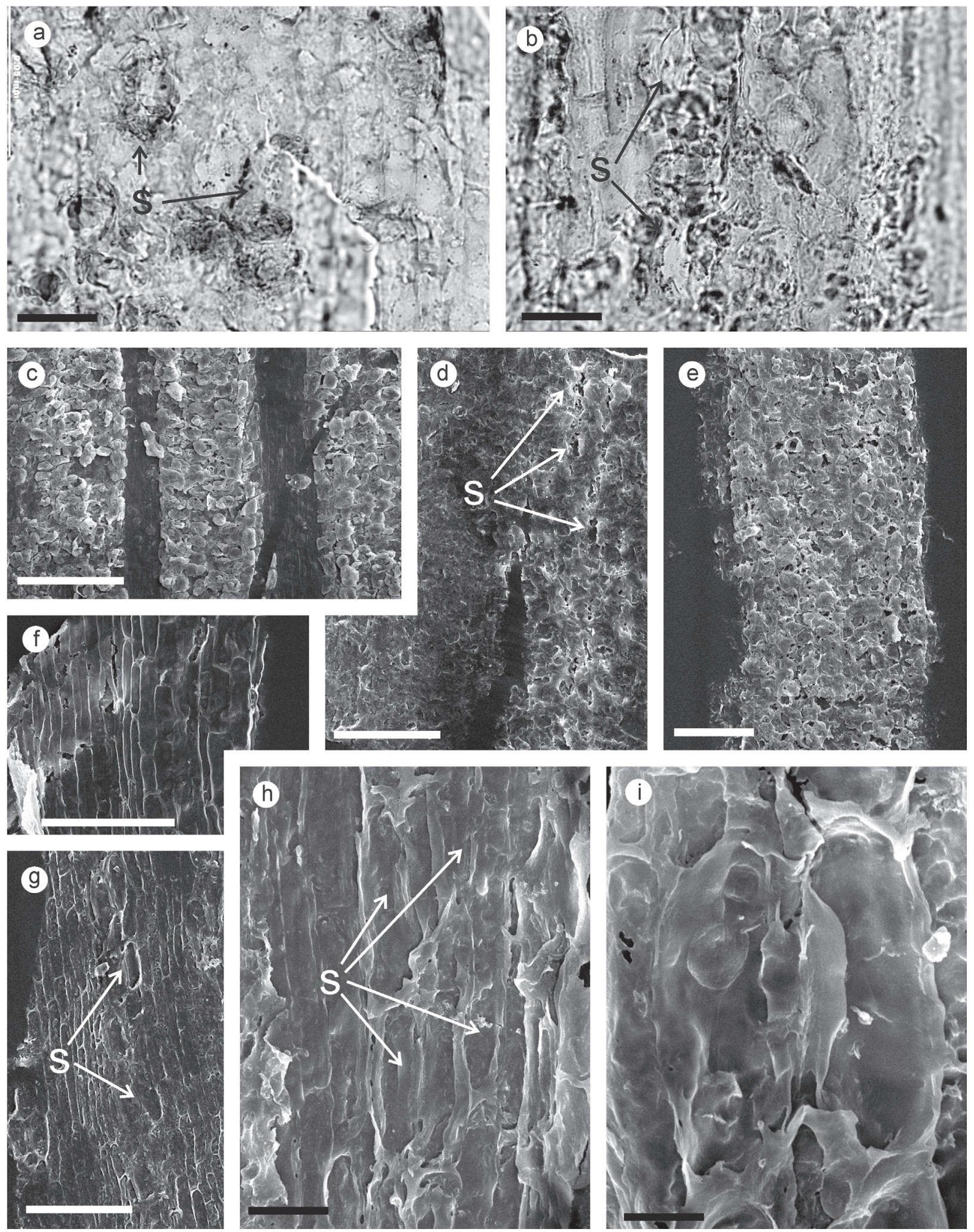

Fig. 19. Cordaites vraninoensis Šimůnek and Tenchov sp. nov., cuticles from Vranino and Krupen localities (see Fig. 17), Figs. 19c-i SEM images, stub 60, 19c-e - Krupen locality, 19f-i - Vranino locality.

a, b - Abaxial cuticle with stomata (s) in stomatiferous band, slide 536/3, scale bar $25 \mu \mathrm{m}$, a - slide 536/3, b - slide 538/9;

c, e-Subepidermal tissue, scale bar $100 \mu \mathrm{m}$;

$\mathrm{d}$ - Outer view to (adaxial?) cuticle with stomatal openings (s);

$\mathrm{f}, \mathrm{g}$ - Inner view to adaxial cuticle, $\mathrm{g}$ - with two stomatal complexes (s);

$\mathrm{h}$ - Inner view to abaxial cuticle with stomatal complexes, scale bar $20 \mu \mathrm{m}$;

$\mathrm{i}$ - Close up of stomatal complex from abaxial cuticle, scale bar $10 \mu \mathrm{m}$; 
Material: Two specimens: one from the Vranino locality, borehole R 139, depth 1594 m (Gurkovo Formation, Asturian strata), and another from the Makedonka locality, borehole R 131, depth 1503 m (Krupen Formation, Bolsovian/Asturian strata). Specimens Nos ZŠ 459 and 460 (orig. Nos.12866, 12048) and slides 538/1-21; 536/1-12.

Diagnosis: Narrow to moderately wide, amphistomatic leaves with moderately-dense venation. One to three thin veins alternate with a doubled thick vein. Cells of abaxial and adaxial cuticles oblong; stomatal complexes of adaxial cuticle in stomatal rows, of abaxial cuticle in stomatiferous bands - they do not form regular stomatal rows. Lateral subsidiary cells narrow, reniform.

Description of hand specimens. Sample No. ZŠ 460 is from a leaf beneath the rock surface and was obtained after dissolving part of the rock. Therefore it is impossible to give a morphological description (the venation is shown on Fig. 17d).

Holotype. Sample No. ZŠ 459 represents several leaf fragments that belong to one species (Fig. 17a). The cuticles on slides 538/1-21 came from about three leaves, the length being limited by the core dimension $-70 \mathrm{~mm}$. Their width varies from 18 to $25 \mathrm{~mm}$. Leaf margins are parallel. The venation is moderately dense $-22-26$ thick veins per mm. The thick vein seems to be doubled, with a shallow furrow in the middle (Fig. 17b). Usually 1-3 thin veins alternate with each doubled thick vein (Fig. 17c).

The adaxial cuticle is formed by dark stomatiferous bands (90-130 $\mu \mathrm{m}$ wide) normally with a single stomatal row in the middle; they are separated by non-stomatiferous bands of two thicknesses (60-70 $\mu \mathrm{m}$ and 20-30 $\mu \mathrm{m})$, thus forming a characteristic pattern (Figs 18a, b). The costal cells are oblong, $30-80 \mu \mathrm{m}$ long and $8-15 \mu \mathrm{m}$ wide (Fig. 18c, d, f). The ordinary cells of the stomatal rows are also oblong, of the same dimension as cells of the costal band. Stomata occur in rows within dark coloured cell areas (Fig. 18c, d, f). The guard cells are elliptical, 25-30 $\mu \mathrm{m}$ long and 5-10 $\mu \mathrm{m}$ wide. The polar subsidiary cells are oblong elongate, $20-50 \mu \mathrm{m}$ long and 8-15 $\mu \mathrm{m}$ wide. The lateral subsidiary cells are also oblong elongate, 45-60 $\mu \mathrm{m}$ long and 10-15 $\mu \mathrm{m}$ wide. The stomatal complex is $60-100 \mu \mathrm{m}$ long and $30-40 \mu \mathrm{m}$ wide. The crypt is slightly prominent, forming an oval above the guard cells, and is 15-20 $\mu \mathrm{m}$ long and 8-14 $\mu \mathrm{m}$ wide. The stomatal density varies between 140-170 stomata per $\mathrm{mm}^{2}$ and the stomatal index is 5-9. The margins of this hollow are concave. Otherwise, each stoma is surrounded by 4 subsidiary cells.

The abaxial cuticle is differentiated into stomatiferous bands and non-stomatiferous bands. The cuticle is weakly cutinized and poorly preserved, and so difficult to observe. The stomatiferous bands, $100-140 \mu \mathrm{m}$ wide, are formed by 3 or 4 stomatal rows (Fig. 18e), and alternate with non-stomatiferous bands, $20-45 \mu \mathrm{m}$ wide. The cells of the non-stomatiferous bands are oblong, 40-70 $\mu \mathrm{m}$ long and $8-15 \mu \mathrm{m}$ wide; the ordinary cells of stomatiferous bands are somewhat obscure, square to rounded, 15-20 $\mu \mathrm{m}$ in diameter. Details of the stomatal complexes, which are 55-70 $\mu \mathrm{m}$ long and 30-40 $\mu \mathrm{m}$ wide, are only partly observable. The sunken guard cells are elliptical with swallow-tail polar ends, 15-30 $\mu \mathrm{m}$ long and
8-15 $\mu \mathrm{m}$ wide. Their exact dimension is often difficult to estimate due to overlapping of subsidiary cells. Better results were achieved by observing the stomata under SEM (Figs 19h, i). The polar subsidiary cells are square, oblong, circular, or oval, 15-25 $\mu \mathrm{m}$ long and 10-20 $\mu \mathrm{m}$ wide. The lateral subsidiary cells are oblong or reniform, 35-50 $\mu \mathrm{m}$ long and 12-22 $\mu \mathrm{m}$ wide. The crypt is not developed. Stomatal density is 470-500 stomata per $\mathrm{mm}^{2}$. The stomatal index varies between 17 and 23 .

Cuticles with subepidermal tissue (Figs 17e, f, g, h, $19 \mathrm{c}$, e). Subepidermal tissue is preserved and stuck to many of the cuticles. Unfortunately, it hides the cellular structures and it is not possible to decide if the cuticle is adaxial or abaxial. The subepidermal tissue forms bands 100-200 $\mu \mathrm{m}$ wide consisting of small rounded cells, 20$30 \mu \mathrm{m}$ in diameter (Fig. 17e), or oval cells, 25-35 $\mu \mathrm{m}$ long and 10-15 $\mu \mathrm{m}$ wide (Fig. $17 \mathrm{~g}$ ). Only costal cells, 30-50 $\mu \mathrm{m}$ long and about $10 \mu \mathrm{m}$ wide are visible in the cuticle (Fig. 17g).

Comparison. The abaxial cuticle of Cordaites vraninoensis is very similar to that of the Asturian species Cordaites wilkischensis Šimůnek. The stomatal complexes of both species are narrow, elongated, and individual stomatal rows within a stomatiferous band are mutually shifted. However, their adaxial cuticles are quite different. Whereas the Bohemian C. wilkischensis is hypostomatic, without stomata on the adaxial cuticle, C. vraninoensis has regular stomatal rows on the adaxial cuticles.

Remarks. Type D cuticles are defined by stomatiferous bands in which individual stomatal rows cannot be distinguished. These stomatiferous bands are separated by non-stomatiferous bands. Cordaites vraninoensis has such stomatiferous bands, but details of the stomatal complexes are difficult to observe due to poor preservation. The anticlinal walls of the subsidiary cells are not prominent and it seems that lateral subsidiary cells are reniform, and this species should belong to the Type C.

\section{Cordaites of the Cantabrian Substage}

\section{Cordaites sp. A (Figs 20, 21)}

Material: One specimen from the Vranino locality, borehole R 139, depth 1524 m, Gurkovo Formation, Cantabrian Substage. Specimen No. ZŠ 461 (orig. No. 12773), slides 410/1-5.

Description of hand specimen (Fig. 21a). The leaf fragment is $65 \mathrm{~mm}$ long and incomplete, and $28 \mathrm{~mm}$ wide. The venation is moderately dense $-22-24$ veins per $\mathrm{mm}$. One to three thin veins alternate with one thick vein (Figs $21 \mathrm{~b}, \mathrm{c})$. Near the margin, the venation is less prominent. It is possible that several leaves were macerated.

The cell structure on the adaxial cuticle (Figs 21d, e) is difficult to observe because often obscured by 'bands' of adhering subepidermal tissue, $140-175 \mu \mathrm{m}$ wide. The costal (non-stomatiferous) rows are either $40-80 \mu \mathrm{m}$ or 10-20 $\mu \mathrm{m}$ wide. The cells in the costal area are oblong, 40-75 $\mu \mathrm{m}$ long and 10-15 $\mu \mathrm{m}$ wide. These small rounded dark cells of subepidermal tissue are not the same density over the whole surface, making it possible to reconstruct the stomata by means of a Camera Lucida attachment 


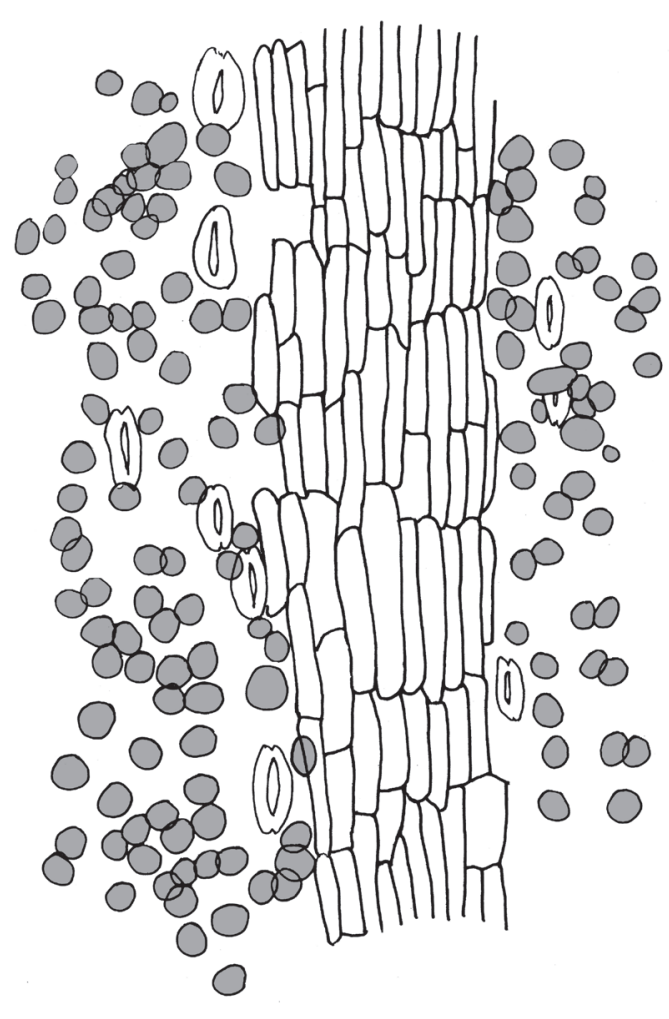

a

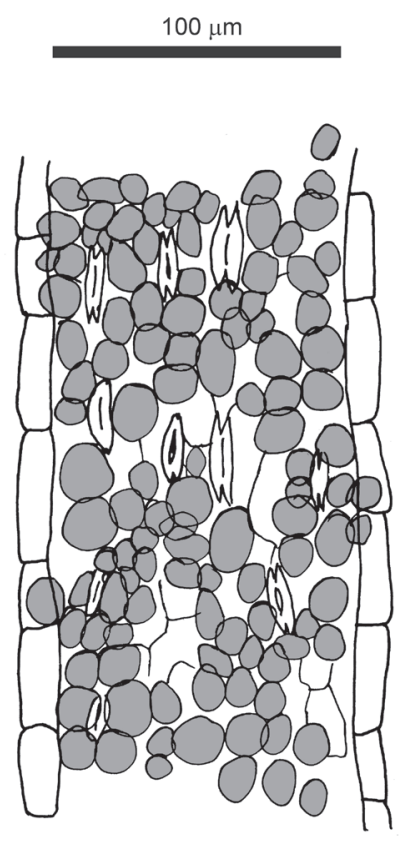

b

Fig. 20. Cordaites sp. A

a - Adaxial cuticle with a non-stomatiferous band and parts of stomatiferous bands with stomata and rests of subepidermal tissue (grey) slide 410/3 (Pl. 19D, E),

b - Abaxial cuticle with stomatiferous band and stomata and rests of subepidermal tissue (grey), slide 410/4, scale bar $100 \mu \mathrm{m}$.

(Fig. 20a). The stomata are elliptical, 22-30 $\mu \mathrm{m}$ long 10$15 \mu \mathrm{m}$ wide. It is not possible to estimate the stomatal density or calculate the stomatal index.

The abaxial cuticle shows dark stomatal rows and nonstomatiferous bands (Figs 20b, 21e-i). The cells of the non-stomatiferous bands are oblong, 50-100 $\mu \mathrm{m}$ long and 12-20 $\mu \mathrm{m}$ wide. The cells of the dark stomatal rows are oblong, square, oval or circular, normally only 20-50 $\mu \mathrm{m}$ long and 15-30 $\mu \mathrm{m}$ wide. The anticlinal walls are bent. The guard cells are elliptical, with swallow-tail polar ends, 18-32 $\mu \mathrm{m}$ long and 10-15 $\mu \mathrm{m}$ wide. The subsidiary cells are of the same shape and dimensions as ordinary epidermal cells. The outer stomatal cavity is not developed. Stomatal density is estimated at 130 stomata per $\mathrm{mm}^{2}$, the stomatal index at 9 .

Comparison. This species is difficult to compare with other species because the inner surface of both adaxial and abaxial cuticles is densely covered by subepidermal tissue, obscuring the ordinary epidermal cells. We can see only guard cells in some cases, and cells of the costal fields. There are only two known species with stomatiferous bands on both adaxial and abaxial cuticles: $C$. principalis Type 5 of Zodrow et al., (2000) from the Bolsovian of Canada and Cordaites radcicensis Śmůnek from the Cantabrian of Bohemia. Cordaites sp. A also comes from the Cantabrian, but without knowledge of cell shape any comparison is excluded.

Remarks. The cuticles of Cordaites sp. A are poorly preserved and cells on the abaxial cuticle are arranged into stomatiferous and non-stomatiferous bands. Details of the cells are not observable. It seems that this species belongs to Type D.

\section{Cordaites gurkovoensis Šimůnek and Tenchov sp. nov. (Figs 22-24)}

Holotype: Here designated (Fig. 23a), Czech Geological Survey, Prague, inv. No. ZŠ 462, coll. Y. Tenchov (Orig. No. 12775).

Derivation of name: After Gurkovo village.

Type locality: Vranino, borehole R 139, depth 1524.

Type horizon: Gurkovo Formation, Pennsylvanian Subsystem, Stephanian Stage, Cantabrian Substage (Moscovian Stage).

Material: Slides 537/1-3.

Diagnosis: Relatively narrow amphistomatic leaves with parallel margins and moderately dense venation. Zero to one thin vein alternates with each thick vein. Cells of adaxial and abaxial cuticles are oblong. Stomatal complexes of adaxial cuticles in dark stomatal rows have 2 

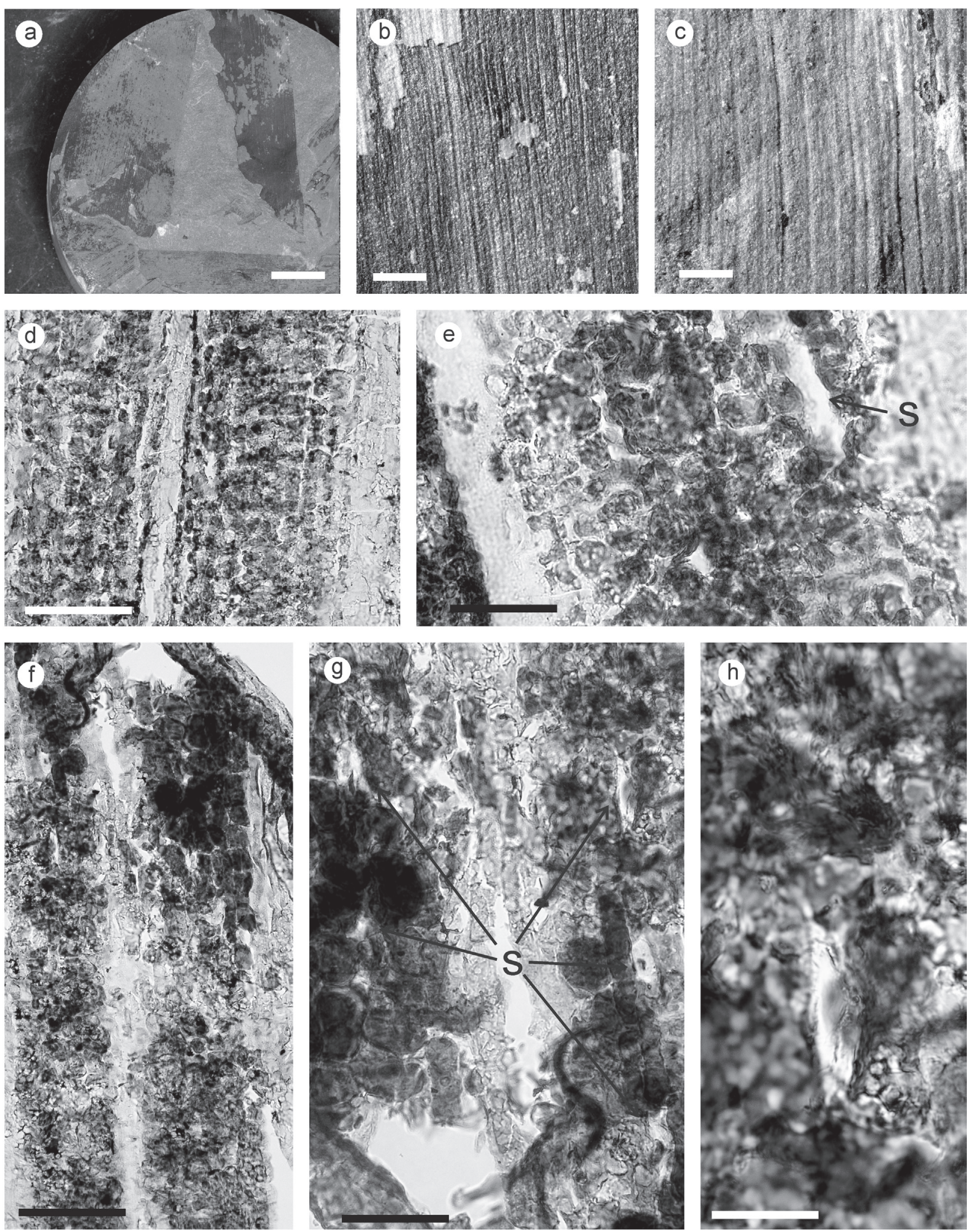

Fig. 21. Cordaites sp. A, Vranino locality, borehole R 139, depth 1524 m, Gurkovo Formation, Cantabrian. a - Leaf fragment No. ZŚ 461 (orig. No. 12773), scale bar $1 \mathrm{~cm}$;

b, c - Venation from the leaf on Fig. 21a, scale bar $1 \mathrm{~mm}$;

$\mathrm{d}$ - Adaxial cuticle with two stomatiferous bands, slide 410/3, scale bar $100 \mu \mathrm{m}$;

e - Close up of stomatiferous band of adaxial cuticle with a stoma (s), slide 410/2, scale bar $50 \mu \mathrm{m}$;

f - Abaxial cuticle with two stomatiferous bands, slide 410/4, scale bar $50 \mu \mathrm{m}$;

$\mathrm{g}$ - Close up of abaxial cuticle with stomatal complexes (s) from Fig. 21f, scale bar $50 \mu \mathrm{m}$;

$\mathrm{h}$ - Close up of the stomatal complex from Fig. $21 \mathrm{~g}$, guard cells with swallow tail polar ends, scale bar $20 \mu \mathrm{m}$. 


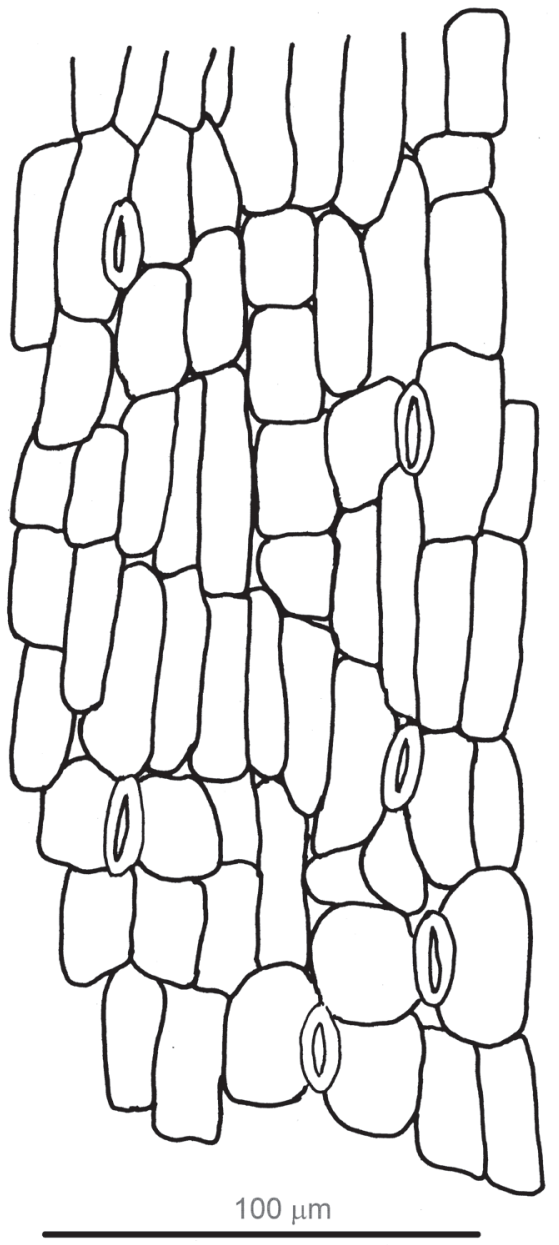

Fig. 22. Cordaites gurkovoensis Šimůnek and Tenchov sp. nov., Abaxial cuticle with stomata in rows, slide 537/3. Scale bar $100 \mu \mathrm{m}$.

oval lateral subsidiary cells and 2 more or less rounded small polar subsidiary cells. Crypt is oblong, prominent. Stomatal complexes of abaxial cuticle arranged into stomatiferous bands, stomatal rows not prominent. Lateral subsidiary cells oblong to oval, similar to ordinary epidermal cells.

Description of holotype. The leaf fragment is $65 \mathrm{~mm}$ long and $21.5 \mathrm{~mm}$ wide. The venation is moderately dense $-22-24$ veins per $\mathrm{cm}$. One or zero thin veins present between two thick veins (Fig. 24b). The veins are not observable up to $2 \mathrm{~mm}$ from the leaf margin.

The adaxial cuticle shows cells of dark stomatal rows and cells of non-stomatiferous (costal) bands (Figs 23c, d). The costal cells are usually oblong, rarely elongated pentagonal or trapezoidal, 40-100 $\mu \mathrm{m}$ long and 15$30 \mu \mathrm{m}$ wide. The ordinary cells of stomatal rows are usually oblong, 35-60 $\mu \mathrm{m}$ long and 20-25 $\mu \mathrm{m}$ wide. Anticlinal walls are slightly bent. Stomata are sparsely distributed in dark rows. The guard cells cannot be seen, because they are covered by a strongly cutinised crypt with an oblong hollow in the middle, 15-20 $\mu \mathrm{m}$ long and 4-8 $\mu \mathrm{m}$ wide (Fig. 23d). The margins of this hollow are concave. Each stoma is surrounded by 4 subsidiary cells. Polar subsidiary cells are oval to oblong, $30-35 \mu \mathrm{m}$ long and $25-28 \mu \mathrm{m}$ wide. Lateral subsidiary cells are reniform, 40-60 $\mu \mathrm{m}$ long and $28-35 \mu \mathrm{m}$ wide. Each stomatal complex is 70-80 $\mu \mathrm{m}$ long and $60-65 \mu \mathrm{m}$ wide. The stomatal density is about 27 stomata per $\mathrm{mm}^{2}$ and the stomatal index is about 3.

The abaxial cuticle is differentiated between stomatiferous bands and non-stomatiferous bands. The cells of non-stomatiferous bands and the ordinary cells of stomatiferous bands are oblong, $40-75 \mu \mathrm{m}$ long and 15-20 $\mu \mathrm{m}$ wide. The guard cells are elliptical, 30-38 $\mu \mathrm{m}$ long and 20-25 $\mu \mathrm{m}$ wide (Fig. 24a, b). The cell outlines are difficult to trace, unless using a Camera Lucida attachment. The subsidiary cells can be similar to the ordinary cells or much wider (Fig. 22). The margin towards the stoma is slightly wavy (Fig. 23f). Usually three of these "irregular" stomatal rows form a stomatiferous band. The crypt is not prominent. Stomatal density is $80-90$ stomata per $\mathrm{mm}^{2}$. The stomatal index is about 5 .

Structures after bacterial or fungal infection (Figs 24 $\mathrm{d}-\mathrm{f}$ ). Under SEM, small objects with hexagonal holes are observed. These are about $20 \mu \mathrm{m}$ in diameter and the holes are 3-8 $\mu \mathrm{m}$ in diameter.

Comparison. The adaxial cuticle of Cordaites gurkovoensis is similar to Cordaites melnicensis. The stomata of both species are arranged into dark stomatal rows on the adaxial cuticle. The abaxial cuticle of $C$. gurkovoensis is poorly preserved but it seems that stomatal complexes are arranged into stomatiferous bands. Figure 22 shows the distribution of the stomata. The venation of C. gurkovoensis is slightly denser than in C. melnicensis from Bohemia and Bulgaria. The Bohemian material

Fig. 23. Cordaites gurkovoensis Šimůnek and Tenchov sp. nov., Vranino locality, borehole R 139, depth 1524, Gurkovo Formation, Cantabrian.

a - Leaf fragment No. ZŠ 462 (orig. No. 12775), scale bar $1 \mathrm{~cm}$;

$\mathrm{b}-$ Venation from the leaf on Fig. 23a, scale bar $1 \mathrm{~mm}$;

c - Adaxial cuticle with a dark stomatal row, slide 537/3, scale bar $100 \mu \mathrm{m}$;

$\mathrm{d}-$ Close up of stomatal row from Fig. 23c with two stomata, scale bar $50 \mu \mathrm{m}$;

e - Abaxial cuticle with stomataiferous bands, slide 537/2, scale bar $100 \mu \mathrm{m}$;

f - Close up of abaxial cuticle from slide 537/3 with stomatal complexes (s) within a stomatiferous band, scale bar $50 \mu \mathrm{m}$. 

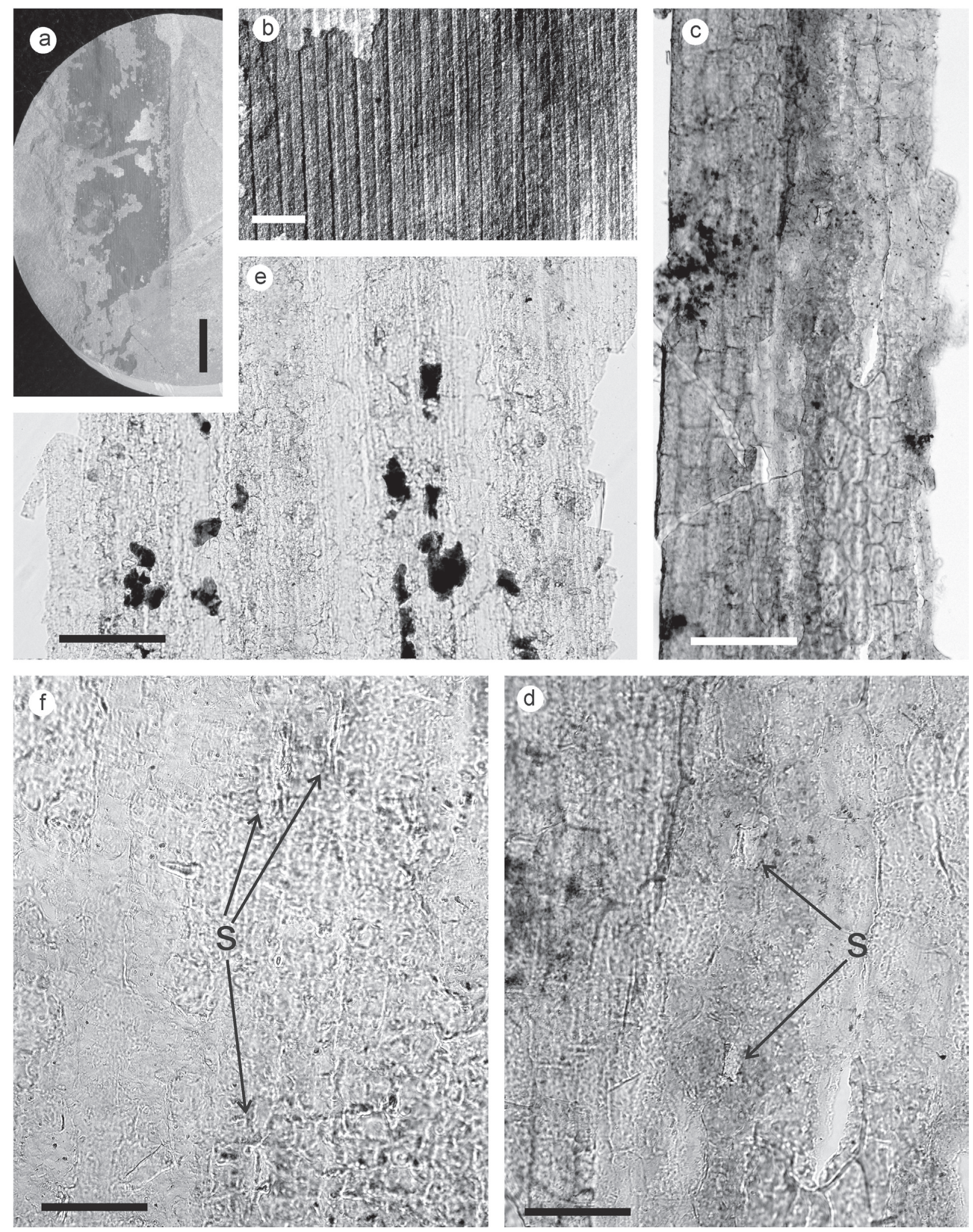

has $12-14$ veins per $\mathrm{cm}$, the Bulgarian $14-18$ veins per $\mathrm{cm}$, whereas $C$. gurkovoensis has $22-24$ veins per $\mathrm{cm}$. C. gurkovoensis has no more than one thin vein between two thick veins, whereas $C$. melnicensis has $1-5$ veins between two thick veins.
Remarks. The venation density of Cordaites gurkovoensis is very low; the distances between stomata are large (Fig. 22). The stomata are arranged into stomatal rows, even irregularly spaced, probably belonging to the Type B. 

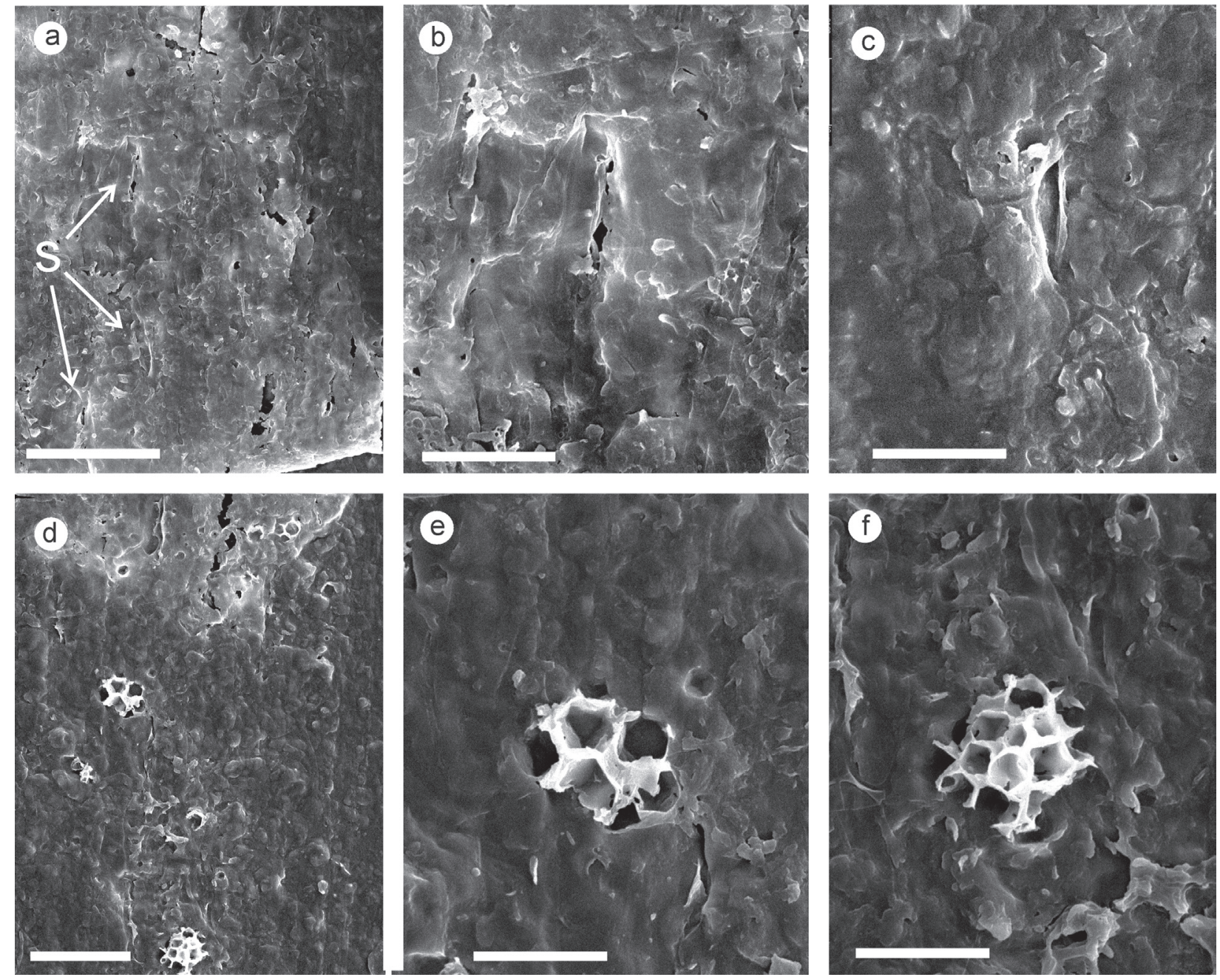

Fig. 24. Cordaites gurkovoensis Šimůnek and Tenchov sp. nov., Vranino locality, borehole R 139, depth 1524, Gurkovo Formation, Cantabrian. SEM images, stub 60.

a - Probably inner view of stomatiferous band of abaxial cuticle with stomata (s); scale bar $50 \mu \mathrm{m}$; b, c - Close up of stomatal complexes from Fig. 24a, scale bars $20 \mu \mathrm{m}$;

$\mathrm{d}$ - Ptobably outer view on the cuticle with bacterial or fungal damage to the cuticle, scale bar $50 \mu \mathrm{m}$; e, $\mathrm{f}-$ Structures after bacterial or fungal infection of the leaf, close up of Fig. 24d, scale bars $20 \mu \mathrm{m}$.

\section{Poorly preserved indeterminable cordaitalean cuticular morphotypes}

\section{Cordaites sp. B (Fig. 25)}

Material: One specimen from the Vranino locality, borehole R 90, depth 1615 m, Mogilishte Formation,
Duckmantian Substage (Moscovian Stage). Specimen No. ZŠ 463 (orig. No. 8453), slides 405/1-4.

Description of hand specimen (Fig. 25a). The leaf fragment is $110 \mathrm{~mm}$ long and $26 \mathrm{~mm}$ wide. The venation is moderately dense $-22-26$ veins per $\mathrm{cm}$. Zero to one thin veins alternate with each thick vein (Figs 25b, c). The thick veins are usually very prominent (Fig. 25b) and

Fig. 25. Cordaites sp. B, Vranino locality, borehole R 90, depth 1615 m, Mogilishte Formation, Duckmantian, g and h - SEM images (stub 27).

a - Leaf fragment No. ZŠ 453 (orig. no. 8453), scale bar $1 \mathrm{~cm}$;

b, c-Venation from different leaves from Fig. 25a, scale bar $1 \mathrm{~mm}$;

$\mathrm{d}, \mathrm{e}-$ Cuticle with oriented cells parallel to veins. The stomatal bands and rows are difficult to observe. It is impossible to judge if the cuticle is adaxial or abaxial, d - slide 405/2, scale bar $100 \mu \mathrm{m}$; e - slide 405/3, scale bar $100 \mu \mathrm{m}$;

f - slide 405/3, scale bar $50 \mu \mathrm{m}$;

$\mathrm{g}$ - Inner view on the cuticle, scale bar $50 \mu \mathrm{m}$;

$\mathrm{h}$ - Inner view on the cuticle, scale bar $50 \mu \mathrm{m}$. 

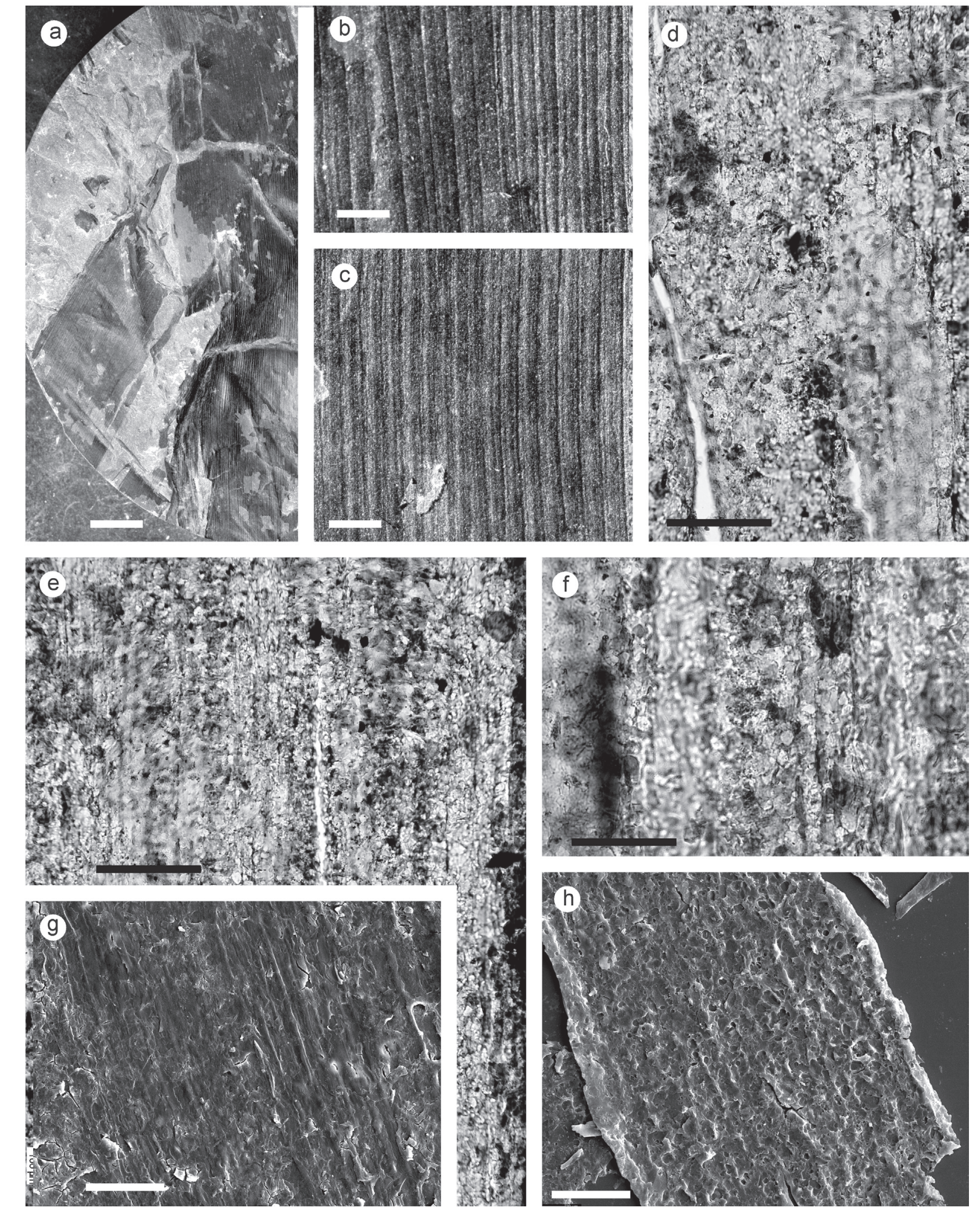

comprise two distinct strands separated by a shallow furrow (Fig. 25c).

The cells of the adaxial cuticle (Fig. 25d) are slightly differentiated into costal and intercostal bands, but the cells are indiscernible over most of the leaf blade. The cells of both areas are oblong, 50-100 $\mu \mathrm{m}$ long and 15-20 $\mu \mathrm{m}$ wide. The anticlinal walls are straight or slightly bent.

The abaxial cuticle is very poorly preserved. The cells, if discernible, are oblong, $40-80 \mu \mathrm{m}$ long and $10-15 \mu \mathrm{m}$ wide. Stomata were preserved in indistinct rows, $70-80 \mu \mathrm{m}$ 
wide. The entire surface of this cuticle is strongly corroded and the original cell structure and stomata are not traceable, even under SEM (Fig. 25g).

\section{Cordaites sp. C (Figs 26, 27)}

Material: One specimen from the Gurkovo locality, borehole R 70, depth 1656 m, Makedonka Formation, Bolsovian Substage (Moscovian Stage). Specimen No. ZŠ 464 (orig. No. 9675), slides 407/1-5.

Description of hand specimen (Fig. 27a). The leaf fragment is over $102 \mathrm{~mm}$ long and $25 \mathrm{~mm}$ wide. The thick veins are rare $-16-18$ veins per $\mathrm{cm}$. Two to four thin veins alternate with each thick vein (Fig. 27b). The thick veins are only slightly thicker than the thin veins. Thick and thin veins are sometimes hardly discernible.

Adaxial cuticle (Figs 27a, d, e): The differentiation between costal and intercostal fields is not prominent. The cells are oblong, 45-75 $\mu \mathrm{m}$ long and 10-15 $\mu \mathrm{m}$ wide. The anticlinal walls are straight.

Abaxial cuticle. The non-stomatiferous cells are oblong, 35-100 $\mu \mathrm{m}$ long and 8-13 $\mu \mathrm{m}$ wide. Anticlinal walls are bent. Stomata occur in stomatal rows (Figs 26, 27f, g). The shape of the guard cells is unclear (Fig. 27f, g), but drawings made by means of a Camera Lucida attachment (Fig. 26) show they are elliptical, 15-20 $\mu \mathrm{m}$ long and $7-10 \mu \mathrm{m}$ wide. The stomatal complex is $50-60 \mu \mathrm{m}$ long and 35-40 $\mu \mathrm{m}$ wide. Polar subsidiary cells are usually oval, $12-20 \mu \mathrm{m}$ in diameter and lateral subsidiary cells are oblong or reniform, 20-30 $\mu \mathrm{m}$ long and 10-15 $\mu \mathrm{m}$

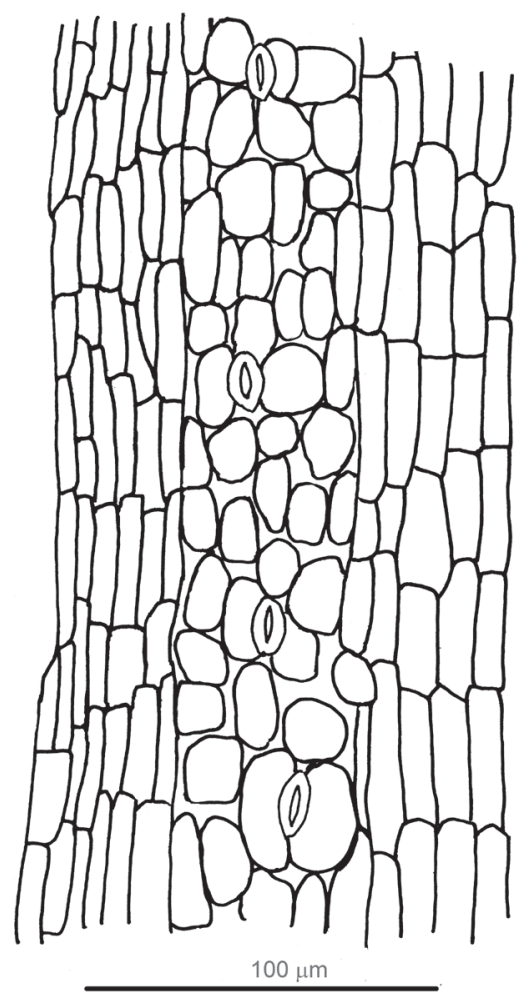

Fig. 26. Cordaites sp. C. Abaxial cuticle with a stomatal row, slide 407/3. Scale bar $100 \mu \mathrm{m}$. wide. The stomatal density is estimated at 130-160 stomata per $\mathrm{mm}^{2}$ and stomatal index at 8-9. The crypt is difficult to observe.

Comparison. This material is poorly preserved. Stomata could not be seen on the adaxial cuticle, but occur in single stomatal rows on the abaxial cuticle. Ordinary cells of the abaxial cuticle are rounded, oblong, oval; stomatal complexes are not very dense within a stomatal row. Only a few species with stomata in single or double stomatal rows on the abaxial cuticle are hypostomatic as Cordaites sp. C. The Bohemian species Cordaites blazkovicensis Šimůnek and Cordaites radvanicensis Šimůnek have stomata on the abaxial cuticle that are sparsely arranged into stomatal rows but the shape of the stomatal complexes is different. Furthermore, both $C$. blazkovicensis and C. radvanicensis are amphistomatic, whereas Cordaites $s p$. C is hypostomatic.

Remarks. Cordaites sp. C has a low stomatal density characteristic of the dispersed stomata of Type A cuticles. The cells of the stomatal rows differ from ordinary cells. This species should be classified to Type B (Fig. 26). This abaxial cuticle resembles that of other species.

\section{Evaluation of venation}

It has been shown that not only length and width of cordaitalean leaves is quite variable, but also the venation pattern of the same species. From Ledran (1966, table 1) it is evident that many species have the same venation pattern and density. Harms and Leismann (1961) demonstrated that Cordaites principalis (Germar) Geinitz and C. crassus Renault have different vein patterns on the adaxial and abaxial sides. This has also been demonstrated by Šimůnek et al. (2009) in Cordaites borassifolius (Sternberg) Unger. Therefore, it is difficult to characterize individual cordaitalean species by means of venation. As a rule, when the venation density (of "thick" veins = vascular bundles) is low, more "thin" veins occur (= sclerenchymatous strands) between two "thick" veins.

Complete leaves are not found in the Bulgarian borehole material and only venation and cuticles can be evaluated. Cordaites mogilishtianus, Cordaites dobrudzhanus and Cordaites sp. C have venation densities of 12-20 veins per $\mathrm{cm}$ and 2-6 thin veins between two thick veins (Table 1). Cordaites makedonkanus and Cordaites cf. melnicensis have the same venation density (14-18 veins per $\mathrm{cm}$ ) but only 1-3 "thin" veins between two thick veins. In contrast, Cordaites gurkovoensis and Cordaites vraninoensis have higher vein density (22-26 veins per $\mathrm{cm}$ ) and only 0-3 "thin" veins between two thick veins. The highest vein densities occur in Cordaites idae and Cordaites schatzlarensis, with 26-40 thick veins per cm, but only $0-1$ thin vein alternating with each thick vein (Table 1). The "thick" veins become thinner and relatively denser, and it is often difficult to distinguish them from "thin" veins.

\section{PALAEOECOLOGY}

Cordaite epidermis is usually formed by rectangular cells and stomatal complexes composed of two guard cells and 

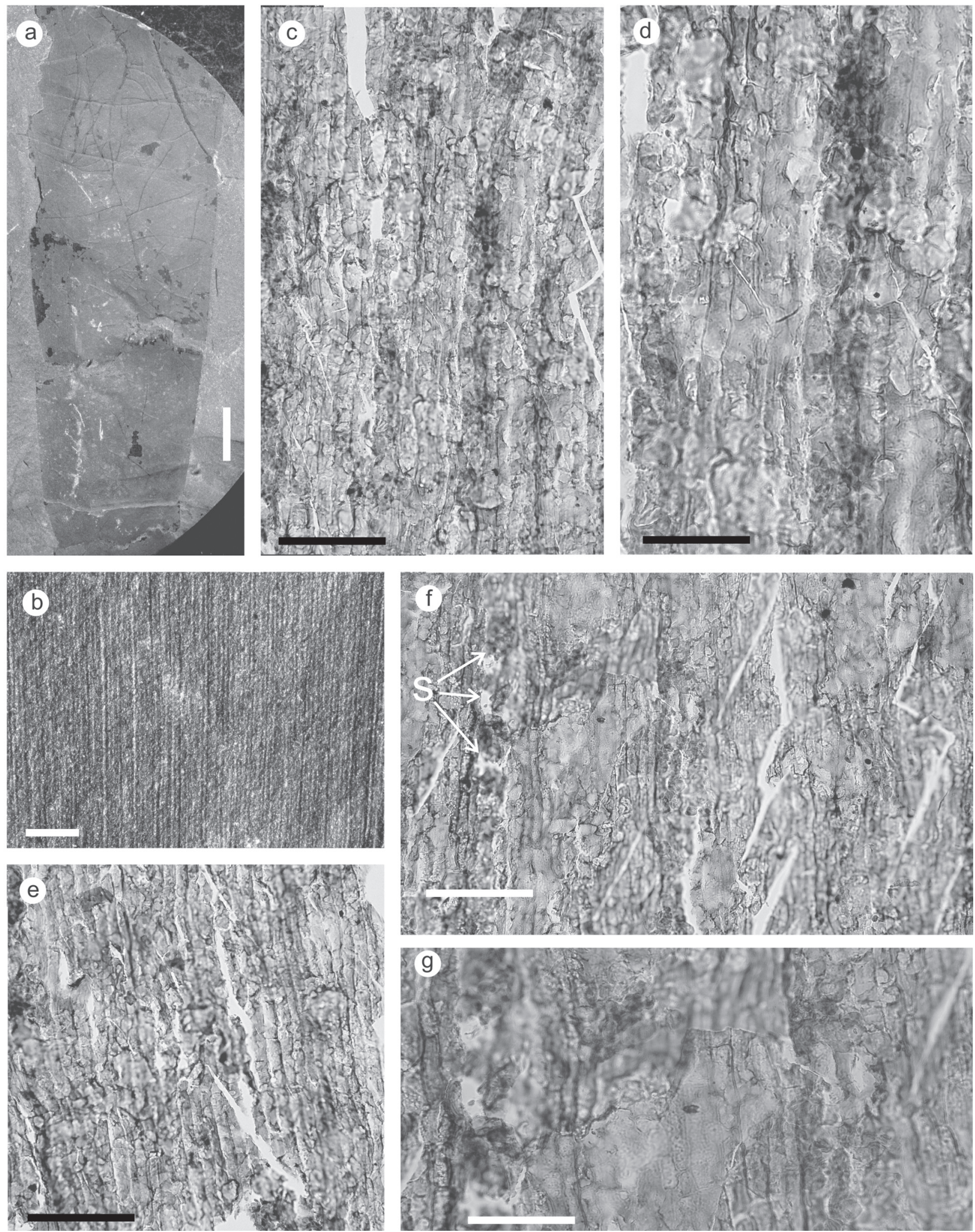

Fig. 27. Cordaites sp. C, Gurkovo locality, borehole R 70, depth 1656 m, Makedonka Formation, Bolsovian.

a - Leaf fragment No. ZŠ 464 (orig. No. 9675), scale bar $1 \mathrm{~cm}$;

b - Venation from the leaf from Fig. 27a, scale bar $1 \mathrm{~mm}$;

c - Cuticle, probably adaxial, with oriented cells parallel to veins, slide 407/2, scale bar $100 \mu \mathrm{m}$;

d - Detail from Fig. 27c, scale bar $50 \mu \mathrm{m}$;

e - Probably also adaxial cuticle, slide 407/2, scale bar $100 \mu \mathrm{m}$;

f - Abaxial cuticle with stomatal rows, stomatal complexes (s), slide 407/3, scale bar $100 \mu \mathrm{m}$;

$\mathrm{g}-$ Close up of two stomatal complexes from Fig. 27f, scale bar $50 \mu \mathrm{m}$. 


Int

IIII

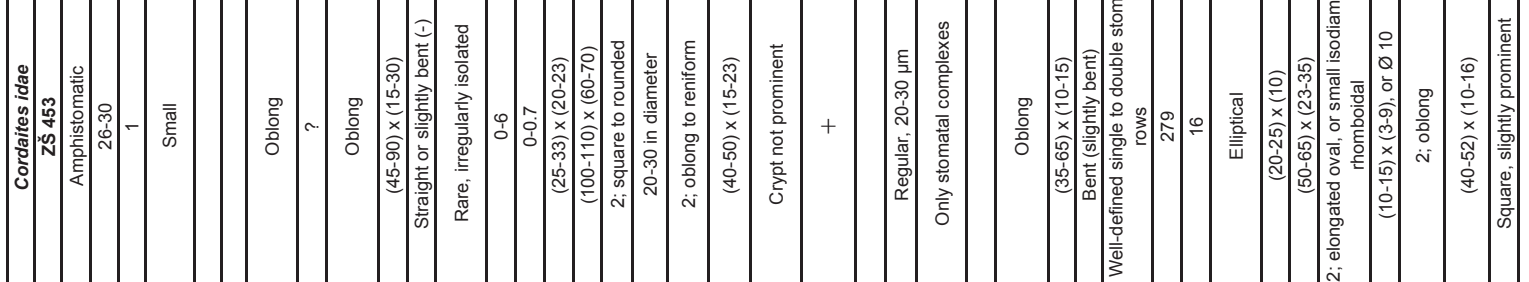

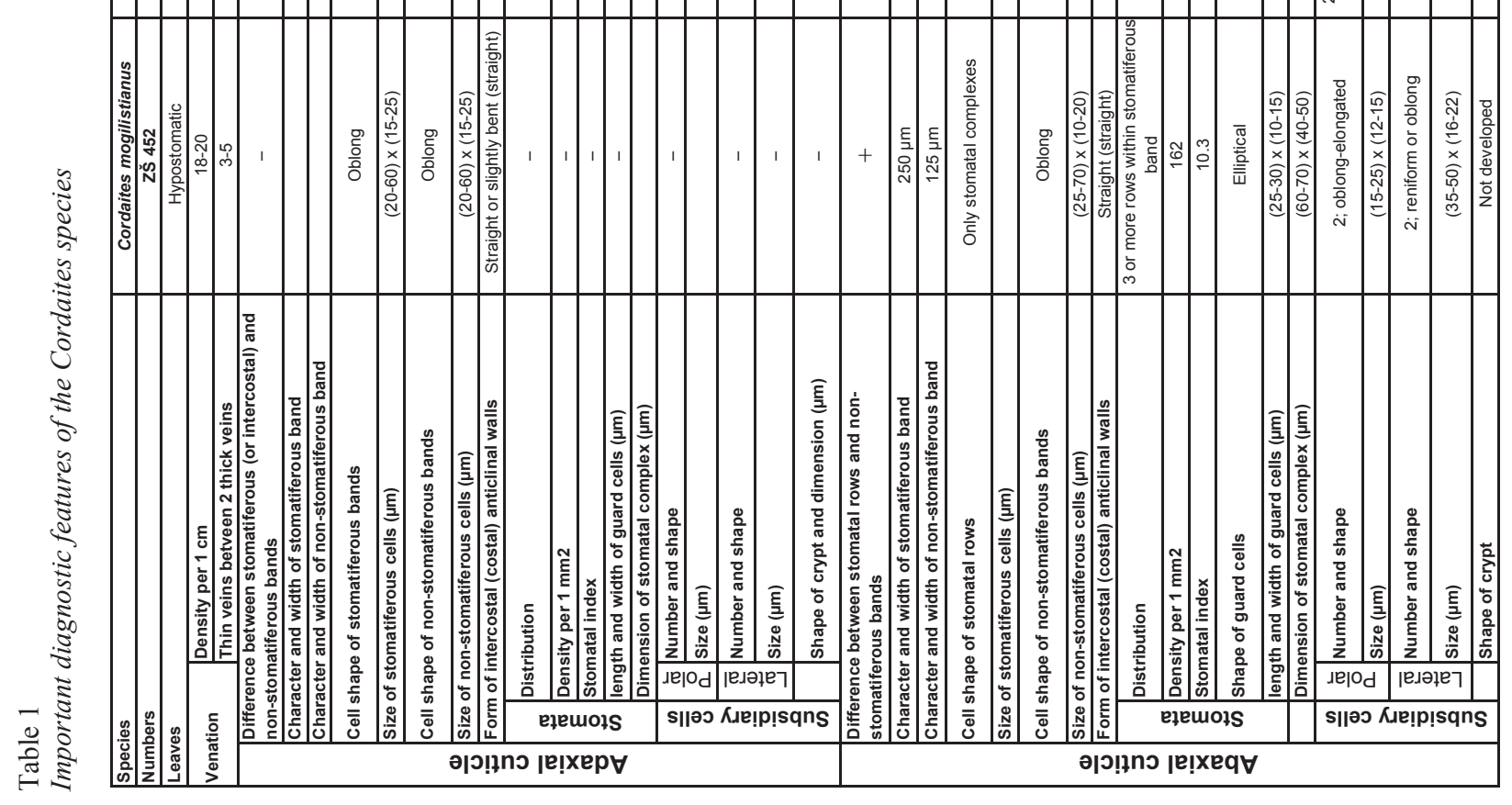




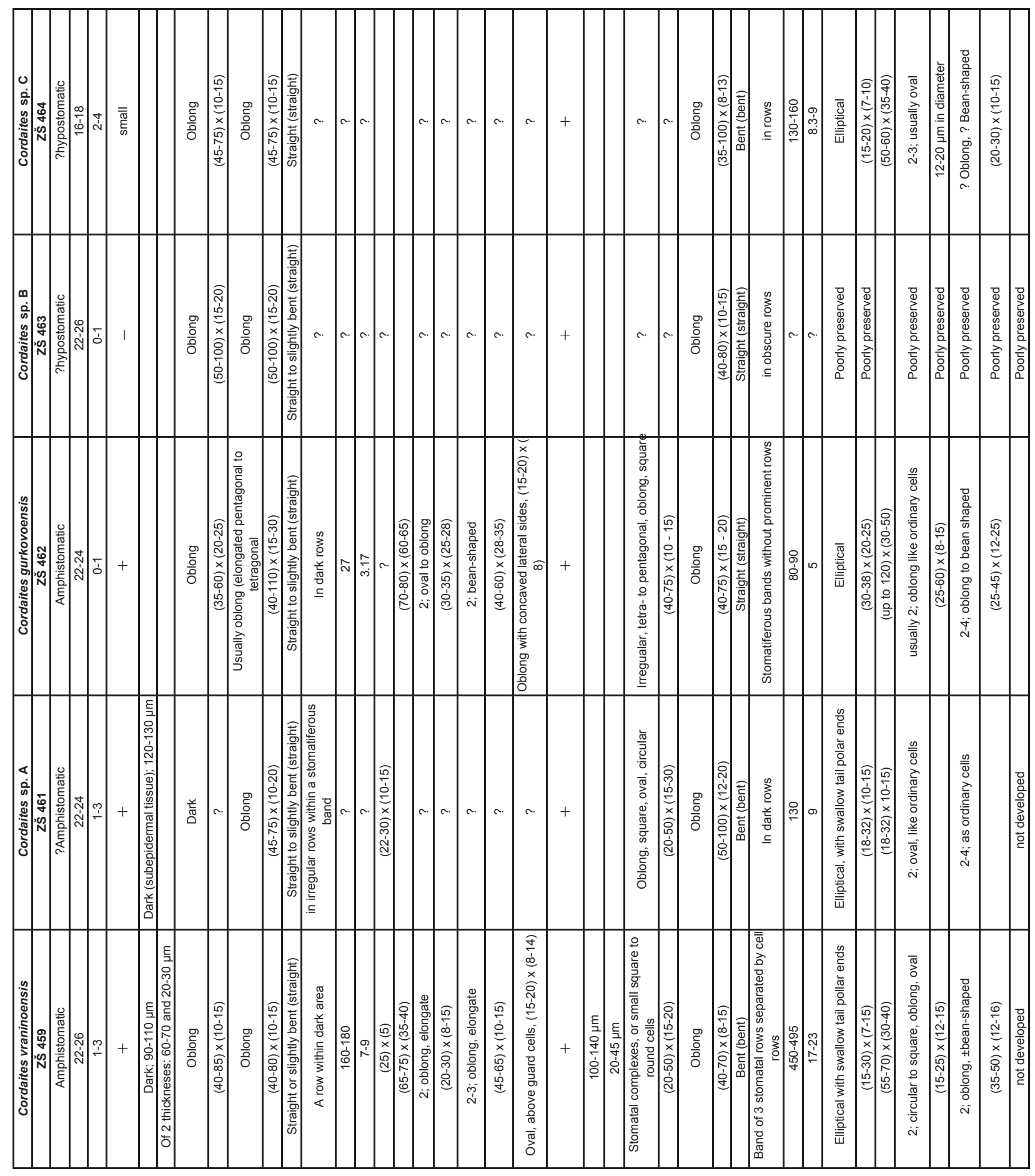


four subsidiary cells. Trichomes and hydathodes have not been observed in Cordaites, whereas sunken guard cells and whole stomatal rows are very common. In many species, cutinised thickenings around the stomatal aperture are developed and form the so-called crypt or outer stomatal cavity. In some cases it is in the form of two papillae. This is adaptation to dryness or physiological dryness. Papillae occur more often in species found in coals than in species from roof shales (Wartmann, 1969). Papillae can have different functions and it is difficult to assess their palaeoecological value (Kerp, 1990, Barclay et al., 2007).

Most Cordaites species are amphistomatic. Some have approximately the same stomatal densities on the adaxial and abaxial side and it is difficult to decide which cuticle is adaxial or abaxial. Such species from the Dobrudzha Basin are Cordaites makedonkanus and Cordaites dobrudzhanus. Other species such as Cordaites cf. melnicensis and Cordaites gurkovoensis have usually lower stomatal densities on adaxial cuticle (25-45 stomata per $\left.\mathrm{mm}^{2}\right)$. Cordaites idae and Cordaites schatzlarenis have very low stomatal densities (0-6 stomata per $\left.\mathrm{mm}^{2}\right)$ on the adaxial cuticle, that can be easily confuse with hypostomatic species such as Cordaites mogilishtianus.

The species with very low densities of stomata on the abaxial cuticle (80-110 stomata per $\mathrm{mm}^{2}$ are Cordaites gurkovoensis and Cordaites cf. melnicensis. C. melnicensis from the Bohemian Massif has approximately 150 stomata per $\mathrm{mm}^{2}$ and Cordaites vraninoensis - 450-495 stomata per $\mathrm{mm}^{2}$.

\section{CONCLUSION}

By means of cuticular analysis 11 Cordaites species have been identified in the Dobrudzha Basin. Five species are here described as new (Cordaites mogilishtianus, Cordaites makedonkanus, Cordaites dobrudzhanus, Cordaites vraninoensis and Cordaites gurkovoensis).
Three others are known from the Bohemian Massif, Czech Republic. Cordaites idae and Cordaites schatzlarensis were previously described from floras of the same age (Duckmantian) of the Intrasudetic Basin. The Bulgarian Cordaites cf. melnicensis is older than the Bohemian one. Due to poor preservation of cuticles, three samples are here described as Cordaites sp. A, Cordaites sp. B and Cordaites sp. C.

This study has confirmed that the venation characteristics can be used only to a limited extent for determining species erected by epidermal features. Venation density and number of "thin" veins between "thick" veins is a very variable feature and depends on the position within the leaf, adaxial or abaxial side and the state of preservation.

In the Bohemian Massif, Cordaites cuticular groups based on cells and stomatal patterns on abaxial cuticles were defined by Šimůnek (2007). In contrast to the Bohemian Massif, where the Types A, B and C are the most common, in the Dobrudzha Basin Type B dominates, being characterised by well-defined stomatal rows. Typical representatives of this type are Cordaites idae, Cordaites schatzlarensis and Cordaites makedonkanus.

Type B is the most common Cordaites cuticular group in the Dobrudzha Basin, followed by Type C (Table 1). The presence of Type $\mathrm{D}$ cuticles is questionable, and Types $\mathrm{A}$ and $\mathrm{E}$ are unknown. All five cuticle groups are known from the Bohemian Massif.

\section{Acknowledgements}

This paper is a contribution to IGCP 575 Project "Pennsylvanian terrestrial habitats and biotas of Southeastern Euramerica". We acknowledge financial support from the Grant Agency of the Czech Republic (grant P210/10/0232). We thank Dr. C. J. Cleal, National Museum Wales, Cardiff, for English revision of this manuscript.

\section{REFERENCES}

Barclay, R., McElwain, J., Dilcher, D., Sageman B. 2007. The Cuticle Database: Developing an interactive tool for taxonomic and paleoenvironmental study of the fossil cuticle record. Courier Forschungs Institut Senckenberg 258, $39-55$.

Barthel, M. 1962a. Mikropaläobotanische Untersuchungen im Rotliegenden des Döhlener Beckens. T. 1. Jahrbuch Staatlichen Museum Geologie und Mineralogie Dresden 1962, 157-175

Barthel, M. 1962b. Zur Kenntnis inkohlter Blätter der Gattung Cordaites Presl. Hallesches Jahrbuch für Mitteldeutsche Erdgeschichte 4, 37-39.

Barthel, M. 1964. Coniferen- und Cordaiten-Reste aus dem Rotliegenden des Döhlener Beckens. Geologie (Berlin) 13(1), 60-89.

Cleal, C. J., Opluštil, S., Thomas, B. A., Tenchov, Y., Abbink, O. A., Bek, J., Dimitrova, T., Drábková, J., Hardkopf-Fröder, C., van Hoof, T., Kedzior, A., Jarzembowski, E., Jasper, K., Libertín, M., McLean, D., Oliwkiewicz-Miklasinska, M., Pšenička, J., Ptak, B., Schneider, J. W., Schultka, S.,
Šimůnek, Z., Uhl, D., Waksmundzka, M. I., van Waveren, I., Zodrow, E. L. 2009. Late Moscovian terrestrial biotas and palaeoenvironments of Variscan Euramerica. Netherlands Journal of Geosciences - Geologie en Mijnbouw 88(4), 181-278.

Di Michele, W. A., Phillips, T. L. 1994. Paleobotanical and paleoecological constraints on models of peat formation in the Late Carboniferous of Euramerica. Palaeogeography, Palaeoclimatology, Palaeoecology 106, 39-90.

Dimitrova, T. Kh., Cleal, C. J. 2007. Palynological evidence for late Westphalian - early Stephanian vegetation change in the Dobrudzha Coalfield, NE Bulgaria. Geological Magazine 144, 513-524.

Falcon-Lang, H. J. 2003a. Late Carboniferous tropical dryland vegetation in an alluvial-plain setting, Joggins, Nova Scotia. Palaios 18, 197-211.

Falcon-Lang, H. J. 2003b. Response of Late Carboniferous tropical vegetation to transgressive-regressive rhytms, Joggins, Nova Scotia. Journal of the Geological Society, London 160, 643-647. 
Falcon-Lang, H. J. 2003c. Anatomically preserved cordaitalean trees from a dryland alluvial plain setting, Joggins, Nova Scotia. Atlantic geology 39, 259-265.

Falcon-Lang, H. J., Bashforth, A. R. 2004. Pennsylvanian uplands were forested by gigant cordaitalean trees. Geology 32(5), 417-420.

Falcon-Lang, H. J., Bashforth, A. R. 2005. Morphology, anatomy, and upland ecology of large cordaitalean trees from the Middle Pennsylvanian of Newfoundland. Review of Palaeobotany and Palynology 135, 223-243.

Falcon-Lang, H. J., Rygel, M, Gibling, M. R., Calder, J. H. 2004. An early Pennsylvanian waterhole deposit and its fossil biota in a dryland alluvial plain setting, Joggins, Nova Scotia. Journal of the Geological Society, London 161, 209-222.

Falcon-Lang, H. J., Scott A. C. 2000. Upland ecology of some Late Carboniferous trees from Nova Scotia and England. Palaeogeography, Palaeoclimatology, Palaeoecology 156, 225-242.

Ge, S. 1991. Cuticle of Cordaites baodeensis sp. nov. from Lower Permian of Baode, NW Shanxi, China with discussion on taxonomy of Cordaites. Acta Palaeontologica Sinica 30(2), 167-185.

Harms, V. L. Leisman, G. A. 1961. The anatomy and morphology of certain cordaites leaves. Journal of Paleontology 35, 1041-1064.

Kerp, H. 1990. The study of fossil gymnosperms by means of cuticular analysis. Palaios 5, 548-549.

Kerp, H., Krings, M. 1999. Light microscopy of fossil cuticles. In: Jones, T. P., Rowe, N. P. (Eds.). Fossil plants and spores. Modern techniques. Geological Society London, $52-56$.

Krings, M. 2000. The use of biological stains in the analysis of the late Palaeozoic pteridosperm cuticles. Review of Palaebotany and Palynology 108, 143-150.

Krings, M., Kerp, H. 1997. An improved method for obtaining large pteridosperms cuticles. Review of Palaeobotany and Palynology 96, 453-456.

Ledran, Ch. 1966. Contributions a l'étude des feuilles de Cordaitales. Théses présentées a la Faculté des Sciences de l'Académie de Reims, Série. 1, 1-154.

Martín-Closas, C., Galtier, J. 2005. Plant taphonomy and palaeoecology of Late Pennsylvanian intramontane wetlands in the Grassessac-Lodéve basin, (Languegoc, France). Palaios 20, 249-265.

Meyen, S. V. 1984. Basic features of gymnosperm systematics and phylogeny as evidenced by the fossol record. The Botanical Review 50(1), 1-111.

Opluštil, S., J. Pšenička J., M. Libertín, M., Bashforth, A. R., Z. Šimůnek Z., J. Drábková, J., Dašková, J. 2009. A Middle Pennsylvanian (Bolsovian) peat-forming forest preserved in situ in volcanic ash of the Whetstone Horizon in the Radnice Basin, Czech Republic. Review of Palaeobotany and Palynology 155, 234-274.

Pant, D. D., Verma, B. K. 1964. The cuticular species of Noeggerathiopsis Feistmantel and Cordaites Unger. Palaeontographica, Abteilung B 115(1-3), 21-44.

Plaziat, J. C., Cavgnetto, C., Hoeniguer, J. C., Baltzer, F. 2001 . History and biogeography of the mangrove ecosystem based on a critical reassessment of the paleontological record. Wettlands Ecology and Management 9, 161-180.

Poole, I., Kürschner, W. M. 1999. Stomatal density and index: the practise. In: Jones, T. P., Rowe, N. P. (Eds.). Fossil plants and spores. Modern technigues. Geological Society London, 257-260.

Rabitz, G. 1966. Cordaiten aus dem flozfuhrenden Oberkarbon des Ruhrgebietes. Fortschritte in der Geologie von Rheinland und Westphalen 13, 303-316.

Raymond, A. 1988. The palaeoecology of a coal-ball deposit from the Middle Pennsylvanian of Iowa dominated by cordaitalean gymnosperms. Review of Palaeobotany and Palynology 53, 233-250.

Raymond, A., Phillips, T. L. 1983. Evidence for an Upper Carboniferous mangrove community. In: Teas, H. J. (Ed.). Tasks for vegetation science 8, 19-30.

Salisbury, J. E. 1927. On the causes and ecological significance of stomatal frequency, with special reference to the woodland flora. Philosophical Transaction of the Royal Society of London 216 B, 1-65.

Scott, A. C., Galtier, J., Mapes, R. H., Mapes, G. 1997. Palaeoecological and evolutionary significance of anatomically preserved terrestrial plants in Upper Carboniferous marine goniatite bullions. Journal of the Geological Society London 154, 61-68.

Šimůnek, Z. 2007. New classification of the genus Cordaites from the Carboniferous and Permian of the Bohemian Massif based on cuticle micromorphology. Acta Musei nationalis Pragae, Series B, Historia Naturalis 62(3-4), 97-210.

Šimůnek, Z. 2008. The Asturian and Cantabrian floral assemblages with Cordaites from the Plzen Basin (Czech Republic). Studia Geologica Polonica 129, 51-80.

Šimůnek, Z., Libertín, M. 2006. Cordaites schatzlarensis sp. nov. and Samaropsis newberryi (Andrews) Seward from the Westphalian (Carboniferous) of the Žaclér area (Czech Republic). Review of Palaeobotany and Palynology 138, 43-62.

Šimůnek, Z., Opluštil, S., Drábková, J. 2009. Cordaites borassifolius (Sternberg) Unger (Cordaitales) from the Radnice Basin (Bolsovian, Czech Republic). Bulletin of Geosciences 84, 2, 301-336.

Taylor, T. N., Taylor, E., Krings, M. 2009. Palaeobotany. The palaeobiology and evolution of fossil plants. Second edition. Elsevier Academic Press, 1230 pp. Amsterdam.

Tenchov, Y. 1993. Sedimentation and erosion during the Late Carboniferous in the Dobrudzha coalfield (northeast Bulgaria). Geologica Balcanica 23, 3-18.

Tenchov, Y.G. 2005. Early Westphalian sediments of Dobrudzha Coalfield (NE Bulgaria) - an interpretation of their stratigraphy and sedimentation conditions. Zeitschrift der Deutschen Gesellschaft für Geowissenschaften 156, 467-480.

Triwett, M. L., Rothwell, G. W. 1985. Morphology, systematics and paleoecology of Paleozoic fossil plants: Mesoxylon priapi sp. nov. (Cordaitales). Systematic Botany 10(2), 205-223.

Unger, F. 1850. Genera et species plantarum fossilium. 627 pp.Wilhelm Braunmüller, Wien.

Wartmann, R. 1969. Studie über die papillen-förmigen verdikkungen auf der Citicule bei Cordaites an Material aus dem Westfal C des Saar-Karbons. Argumenta Palaeobotanica 3, 199-207.

Zodrow, E. L., Šimůnek, Z., Bashforth, A. R. 2000. New cuticular morphotypes of „Cordaites principalis (Germar) Geinitz" from the Canadian Carboniferous Maritimes Basin. Canadian Journal of Botany 78(2), 135-148. 